Universidad de Lima

Facultad de Comunicación

Carrera de Comunicación

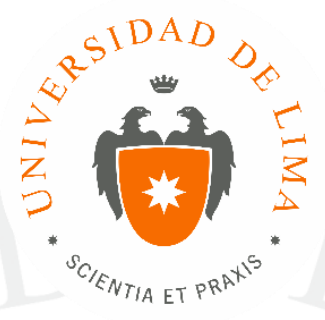

\title{
NARRATIVAS DE LA MANIPULACIÓN DIGITAL EN EL FOTOPERIODISMO PERUANO
}

Trabajo de Investigación para optar el Título Profesional de Licenciado en Comunicación

\section{Jimena Sofía Sánchez Castro}

Código 20101874

\author{
Asesor \\ María Mendoza Michilot
}

Lima - Perú

24 de Octubre de 2017 


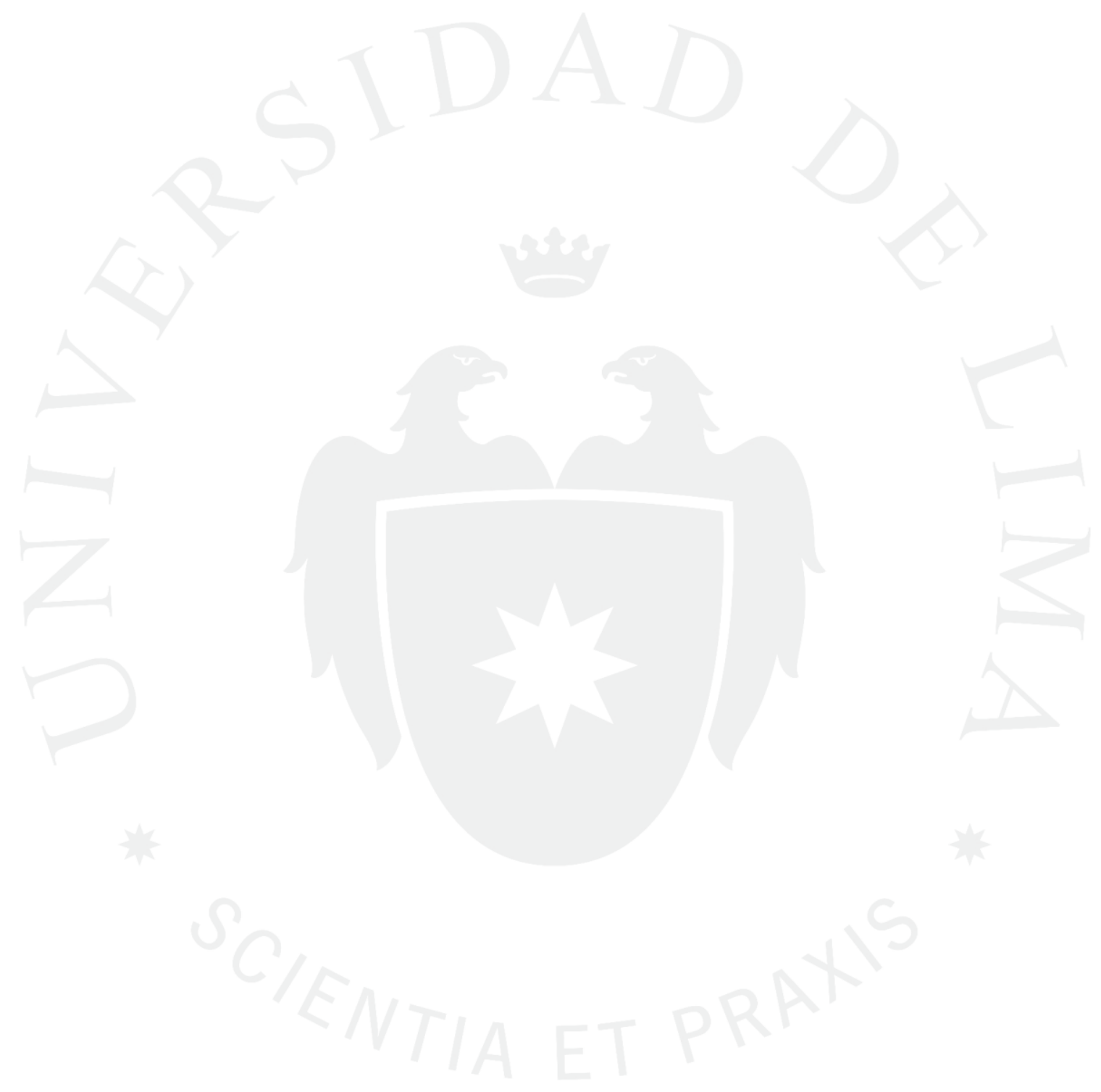


NARRATIVAS DE LA MANIPULACIÓN

DIGITAL EN EL

FOTOPERIODISMO PERUANO 


\section{TABLA DE CONTENIDO}

\section{INTRODUCCIÓN}

\section{CAPÍTULO 1: MARCO TEÓRICO ................... 3}

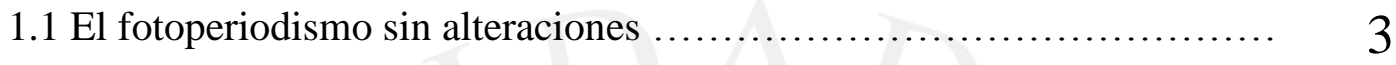

1.2 ¿Manipulación: técnica o exceso? .................................... 4

1.3 La narrativa de la fotografía según la organización de los elementos gráficos........................................................ 6

\section{CAPÍTULO 2: METODOLOGÍA .................... 8}

CAPÍTULO 3: RESULTADOS ...................... 12

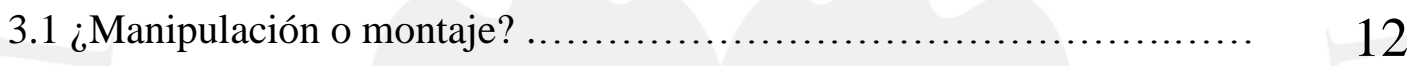

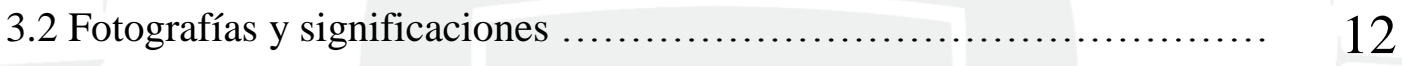

3.2.1 “¿Entra?” o cómo sobrevivir en política .......................... 13

3.2.2 “Otra vez, ¿Amor sin Barreras?” o la maquinación de dos mentes perversas ...................................................... 15

3.2.3 "Rosa de Espinas" o una falsa santa ............................ 17

3.2.4 "No es broma" o el presagio del éxito político ....................... 18

3.3 Una imagen del líder político ...................................... 19

3.4 Una explicación de las líneas editoriales ........................... 22

CONCLUSIONES ...................................... 26

REFERENCIAS ..................................... 29 


\section{ÍNDICE DE TABLAS}

Tabla 1. Los componentes de la imagen que se reconstruye del político

Tabla 2. Los cuatro cuadrantes ......................................................................... 6

Tabla 3. Los componentes de la imagen que se reconstruye de Lourdes Flores ............ 19

Tabla 4. Los componentes de la imagen que se reconstruye de Fujimori y Montesinos 19

Tabla 5. Los componentes de la imagen que se reconstruye de Nadine........................20

Tabla 6. Los componentes de la imagen que se reconstruye de PPK .............................21 


\section{RESUMEN}

La adaptación de los medios de prensa tradicionales a las nuevas tecnologías no ha resuelto antiguos y polémicos problemas en el ejercicio de la profesión como la manipulación de contenidos fotográficos. Este trabajo reflexiona acerca de los límites éticos y tecnológicos que existen en la edición de imágenes en los medios impresos, a partir del análisis de un conjunto de montajes publicados por la revista Caretas. La investigación hace análisis cualitativo de las narrativas y recoge las justificaciones editoriales de los periodistas para continuar con una práctica antigua que se ha perfeccionado tecnológicamente. El principal hallazgo es que el fotomontaje no solo sirve para generar determinados efectos de sentido, sino que consolida estilos y personalidades definidos en la prensa con los efectos que puede generar en la audiencia.

\section{PALABRAS CLAVE:}

Fotografía periodística, fotoperiodismo, manipulación, tergiversación, retoque digital

\section{ABSTRACT}

The adaptation of the traditional media to the new technologies has not solved old and controversial problems in the exercise of the profession as the manipulation of photographic contents. This paper reflects on the ethical and technological limits that exist in the edition of images in the print media, based on the analysis of a set of photomontages published by the magazine Caretas. The research makes qualitative analysis of the narratives and gathers the editorial justifications of the journalists to continue with an old practice that has been perfected technologically. The main finding is that photomontage not only serves to generate certain effects of meaning, but also consolidates styles and personalities defined in the press with the effects it can generate in the audience.

\section{KEYWORDS}

Journalistic photography, photojournalism, manipulation, misrepresentation, digital retouching 


\section{INTRODUCCIÓN}

El montaje periodístico es una práctica que se ha normalizado en beneficio de la calidad de la foto y una mejor lectura de la misma. Con base en un proceso de retoques que buscan connotar antes que denotar, las imágenes sufren cambios notorios y, en ocasiones, pasan desapercibidos. El resultado, sin embargo, es otro significado.

Si el periodismo es un campo que se fundamenta en la veracidad, la autenticidad y la credibilidad, resulta pertinente preguntarse cuáles son los límites de la edición fotográfica en general y el montaje en particular. ¿Hasta qué punto un reportero gráfico puede alterar la imagen? En otras palabras, ¿cuáles son los límites éticos y tecnológicos del fotoperiodismo basado en la manipulación digital?

De todas las publicaciones periodísticas peruanas que priorizan la fotografía como uno de sus recursos fundamentales se seleccionó a la revista Caretas por su trayectoria de más de 60 años en el Perú y porque prácticamente desde su fundación institucionalizó el montaje fotográfico, sobre todo en sus portadas, de una manera única y original, que ha llevado a diferenciarla del resto de los impresos limeños. "Actualidad candente, investigación y humor" es el eslogan de este influyente medio de comunicación que ha hecho de la ironía, la burla y el sarcasmo sus principales herramientas sobre todo cuando se trata de representar la noticia política.

Históricamente, el montaje en Caretas ha sido interpretado como una práctica característica, cotidiana y habitual que se ha justificado ampliamente en diversos factores (políticos, sociales, legales y de difusión) de manera que los recortes, alteraciones y censuras que hace de sus fotos no incomodan a nadie. Salvo algunas coyunturas complicadas (bajo gobiernos de facto, autocracias o la conducción de políticos intolerables), ni siquiera los protagonistas de los montajes que aparecen en las portadas de la revista semanalmente suelen protestar y por lo general toman con humor la representación que de ellos sea hace.

Son pocas las investigaciones orientadas a reconocer que tras el poder mediático de Caretas y la incomparable creatividad de sus gestores para editar sus carátulas subsiste un quehacer significativo y simbólico que merece documentarse.

Esta investigación consideró pertinentes analizar la producción y contenido de fotografías manipuladas por la revista para reconocer los temas y actores resaltados, así 
como los recursos, tergiversaciones y significaciones derivadas de su puesta en escena. En segundo lugar, identificar las prácticas, hábitos y criterios que tiene el semanario sobre el proceso de difusión de la foto. Asimismo, explorar en las percepciones de algunos reporteros gráficos sobre los montajes para sustentar, desde una perspectiva crítica, su alcance en el fotoperiodismo local. 


\section{CAPÍTULO 1: MARCO TEÓRICO}

\subsection{El fotoperiodismo sin alteraciones}

El académico español Manuel de Pablos, según recoge el periodista y profesor, Diego Caballo Ardila, sostiene que el quehacer del fotoperiodismo es publicar imágenes en medios gráficos con la finalidad de que la foto sume al texto informativo como recurso inseparable y necesario. (Caballo, 2006).

Diversos parámetros regulan la práctica de esta especialidad. Por ejemplo, es de rigor que todas las fotos tiendan a expandirse visualmente por la página donde se insertan, de ahí que tengamos que limitar sus posiciones en la plana con recursos tipográficos. Cada imagen de prensa guarda unas proporciones de acuerdo con el mensaje que aporta, es decir, con la armonía que siempre se ha de respetar. Nunca se deben mutilar los extremos informativos de la foto en prensa -sobre todo cuando son parte de la noticia gráfica- por mera estética. (Caballo, 2006).

Estas prácticas y reglas suelen normarse y compilarse en los libros, códigos y manuales de estilo y de ética de algunos medios de prensa. Es el caso del código de la Asociación Nacional de Fotoperiodistas (NPPA, por sus siglas en inglés) que establece: "Editando se debe mantener la integridad del contenido y contexto de la imagen. No se deben manipular las imágenes ni añadir o alterar el sonido de ninguna forma que pueda confundir al público o representar los sujetos de una forma incorrecta" (Asociación Nacional de Fotoperiodistas de Inglaterra, 2012).

Estas reglas no son necesariamente universales, sino que cada medio las establece según sus líneas editoriales. En otros casos, existen, pero no se cumplen sea porque no han sido interiorizadas por los fotoperiodistas o porque los reporteros gráficos de las casas editora desconocen su existencia ${ }^{1}$.

No puede dejar de mencionarse cuánto influye en la aplicación del montaje variables contextuales relacionadas con el desarrollo del diseño y la tecnología. Para algunos académicos, las transiciones estéticas contemporáneas están asociadas a la aparición de símbolos que las sociedades crean y difunden por medio de las tecnologías de información y comunicación (Hernández, 2003). La prensa no está al margen de este proceso y los estilos que adopta en la fotografía periodística no solo están orientados a adquirir una identidad frente al público, sino a ser reconocidos por las técnicas que

\footnotetext{
${ }^{1}$ Entrevista con el fotoperiodista y docente universitario, Jaime Rázuri, efectuada en el año 2014.
} 
utilizan, de las cuales el photoshop es una de las más extendidas.

Señala Macía Barber que el profesor y periodista Luka Brajnovic se preguntaba cómo debía ser el fotoreportero y cuál debía ser su función en el periódico. Su duda giraba en torno a si el periodista es el que informa con su fotografía sobre un acontecimiento o más bien quien sintetiza un suceso con la imagen que logra captar. Lo cierto es que la fotografía de prensa debe proporcionar a los lectores acceso a la realidad, aunque hoy resulta difícil a algunos receptores "percibir la diferencia entre realidad y ficción" debido a las innovaciones que permite la tecnología digital (Maciá, 2002).

La fotomanipulación no es una preocupación reciente y, desde hace décadas, provoca frecuentes cuestionamientos sobre los límites que impone. Pero con el desarrollo de las nuevas tecnologías nunca ha sido más fácil alterar contenidos -pronto será difícil probar estos cambios- ni tampoco incurrir en excesos. Más allá del consabido retoque, se están abriendo nuevas posibilidades narrativas beneficiadas por el tratamiento digital de imágenes, lo cual es una tendencia en proceso de consolidación. (Doménech, 2013).

De esta forma, el fotoperiodismo se ha convertido en una de las actividades periodísticas más observadas y estudiadas por su apego o desapego a las normas relacionadas con el 'deber ser' en el tratamiento de la imagen versus su manipulación, entendiendo este último concepto como sinónimo inicial de tergiversación.

\section{2 ¿Manipulación: técnica o exceso?}

La manipulación no se reduce a una sola definición. Antonio González García (ALOJ, 2015), doctor en Bellas Artes y docente de la Universidad de Sevilla, introduce en sus estudios conceptos clave sobre el uso de colores, composición, encuadre e iluminación de la fotografía, y sobre lo que denomina la "técnica de la manipulación". Desde el clásico paradigma comunicativo de Harold Laswell (quién, qué, cómo, dónde, cuándo y para qué), el autor reconoce la importancia de la noticia en la imagen y los mecanismos de connotación para descubrir el mensaje oculto que se quiere comunicar.

Por su parte, Diego Caballo Ardila (2006), hace clasificación de los tipos de manipulación, concepto que en su opinión adopta diferentes formas y matices.

En primer lugar, sostiene que la manipulación se mide según el posible efecto en los receptores. La de "mayor importancia" es aquella que cambia por completo el significado de la imagen, sin hacer algún tipo de aviso al receptor. También existe la 
manipulación de "importancia media", que es la que advierte y que es realizada de manera más artística y notoria. Y, además, está la manipulación de "menor importancia”, que observa pocos cambios los mismos que suelen pasar desapercibidos. (Caballo, 2006).

En segundo lugar, añade, la manipulación puede observarse según las motivaciones del emisor. Existe la ideológica, que consiste en manipular la imagen o parte de ella para favorecer a la línea ideológica del medio en el que se publica o a un partido político específico. La manipulación económica se da cuando se insertan o eliminan motivos publicitarios que ameriten un gasto económico para el medio. La estética, cuando se quiere que las fotos generen armonía con la estética del medio en el que se publica la imagen. Asimismo, la instrumental consiste en la eliminación de parte de la imagen, modificando su encuadre original para favorecer el diseño y la maquetación del medio en el que la imagen es publicada. Finalmente, la humorística tiene un fin cómico o de burla. (Caballo, 2006).

En tercer lugar, Caballo explica que la manipulación también se mide según la técnica empleada. Tenemos la inserción, que se refiere a la inclusión de nuevos elementos gráficos en la fotografía; la eliminación, que se da cuando se descartan elementos o partes de una imagen; la sustitución, que consiste en incluir un nuevo elemento gráfico con el objetivo de que sustituya alguna otra parte de esta misma foto; finalmente, la duplicación, que se da cuando se utiliza la clonación de ciertas partes de una fotografía con el fin de repetir en la imagen cualquier tipo de objeto que ya existe en ella (2006).

Entre todos los actores sociales con los cuales interactúan los fotoperiodistas, es claro que los políticos son protagonistas frecuentes en representaciones gráficas donde prevalecen las técnicas mencionadas y mediante la cuales se expone su credibilidad, atractividad y poder. (Cabanillas, 2016).

Como señala Imelda Cabanillas (2016), los tempranos estudios de David Berlo, James Lamert y Robert Metz, en el ámbito de la psicología social, pusieron en evidencia los tres componentes de la imagen que se reconstruye del político.

La credibilidad es la principal característica del líder político; sin esta, difícilmente podrá conseguir el apoyo de sus votantes o seguidores. Un líder político creíble da confianza a través de categorías tales como la competencia, es decir, sus dotes de persona preparada y con experiencia; la fiabilidad ética, que busca siempre la 
justicia y el bien común; y el dinamismo, cuando demuestra ser un actor social activo y con mucha energía.

La segunda característica es la atractividad, la cual define al político como alguien interesante. Esta conlleva las siguientes categorías: la similitud, no solo es un sujeto atractivo, sino parecido a 'nosotros'; la proximidad, cuando demuestra capacidad para relacionarse con los demás siempre y es accesible tanto para el resto de líderes políticos como para los ciudadanos; y el agrado, que es la amabilidad y consideración en el trato que despliega o cuando produce una buena impresión.

En cuanto al poder, las categorías que lo complementan son el control y la administración de premios y castigos, apreciables cuando el político demuestra saber aplicar sanciones para garantizar la igualdad social. También es importante el interés que exprese respecto a la opinión del receptor en la toma de decisiones, y finalmente el control de las desviaciones, utilizado implícitamente por el líder político con las personas que le rodean en caso de que estas se alejen de los objetivos planteados.

\begin{tabular}{lll}
\hline CREDIBILIDAD & ATRACTIVIDAD & PODER \\
\hline Competencia & Similitud & $\begin{array}{l}\text { Control y Administración } \\
\text { de premios y castigos }\end{array}$ \\
Fiabilidad ética & Proximidad & $\begin{array}{l}\text { Interés en la opinión del re- } \\
\text { ceptor }\end{array}$ \\
Dinamismo & Agrado & Control de desviaciones \\
\hline
\end{tabular}

Tabla 1. Los componentes de la imagen que se reconstruye del político. Fuente: Cabanillas, 2016.

\subsection{La narrativa de la fotografía según la organización de los elementos gráficos}

Existen diversas propuestas para analizar el discurso de la fotografía periodística. En esta investigación recogemos la propuesta de Gunther Kress, Regina Leite-Garcia y Theo van Leeuwen (2010), quienes evalúan la organización de los diferentes elementos gráficos que la componen por su ubicación.

Dichos autores sostienen que una imagen se puede dividir en cuatro cuadrantes los cuales tienen la potencialidad para representar y comunicar las significaciones de los elementos de la fotografía de acuerdo con su ubicación en cualquiera de ellos. 
En una portada, por ejemplo, hace dos distinciones generales: arriba-abajo y luego izquierda-derecha (Gráfico 1). En la distinción arriba-abajo, a la sección superior de la imagen se le asigna como el valor de lo ideal, es decir, distante en el tiempo, ya sea en el pasado o en el futuro, y a la sección inferior se le llama el valor de lo real, es decir, lo que sucede aquí y ahora.

Con respecto a la distinción izquierda-derecha, lo que se encuentra al lado izquierdo tiende a significar como "lo dado por sentado" o "lo que se supone que es así". Y por el lado derecho, tiende a significar como "lo que es nuevo".

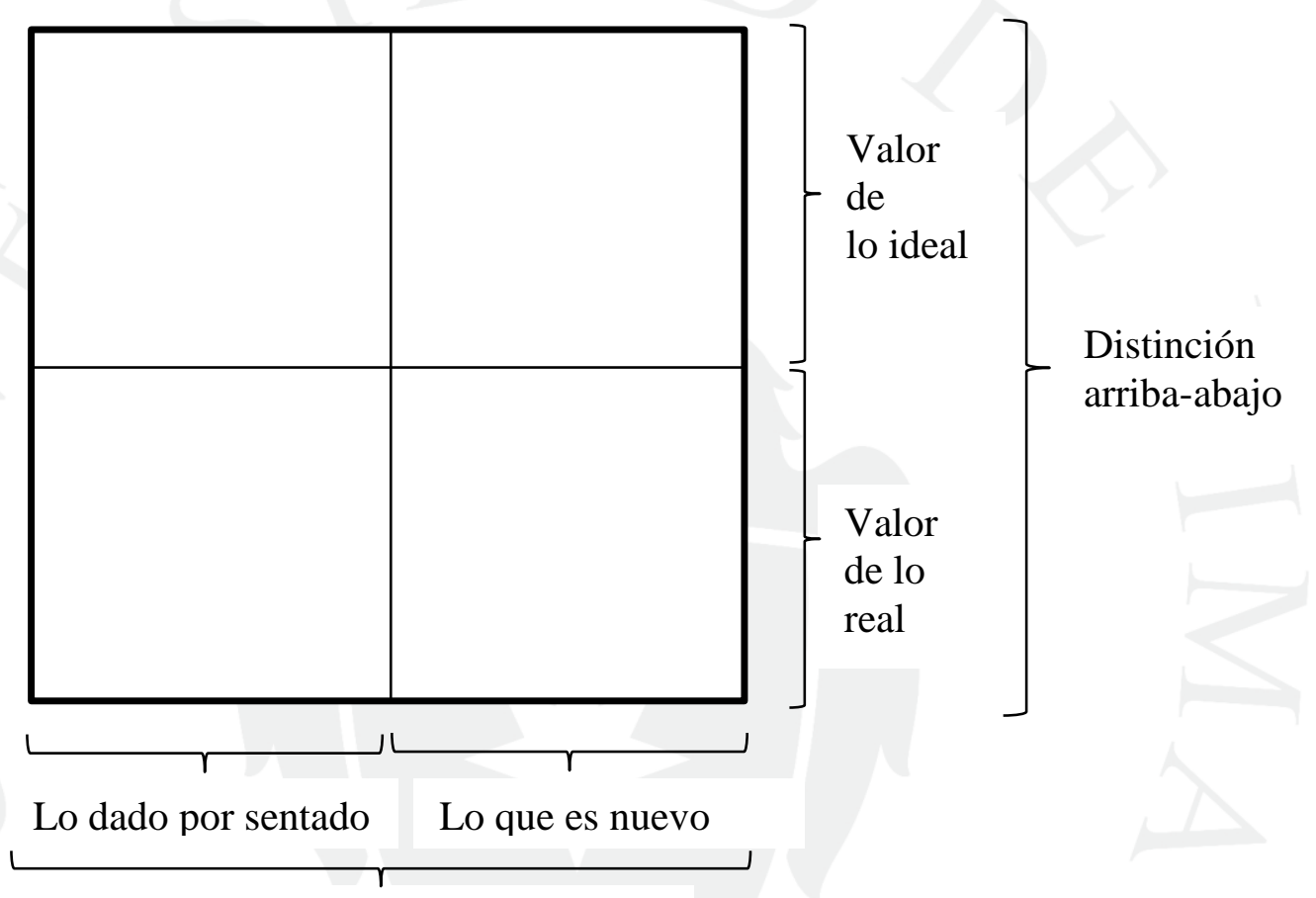

Distinción izquierda-derecha

Tabla 2. Los cuatro cuadrantes. Fuente: Kress, Leite-Garcia y Van Leeuwen, 2010.

La distinción "arriba-abajo" se relaciona con los juicios ontológicos y la distinción "izquierda-derecha" con la información que se tiene a la mano. Según destacan los autores de este modelo, la ubicación de los elementos de cada fotografía no es casual, sino que se relaciona con el interés del productor de la imagen, que los ha colocado ahí por algún motivo, causa, razón o circunstancia. (Kress, Leite-García, \& Van Leeuwen, 2010). 


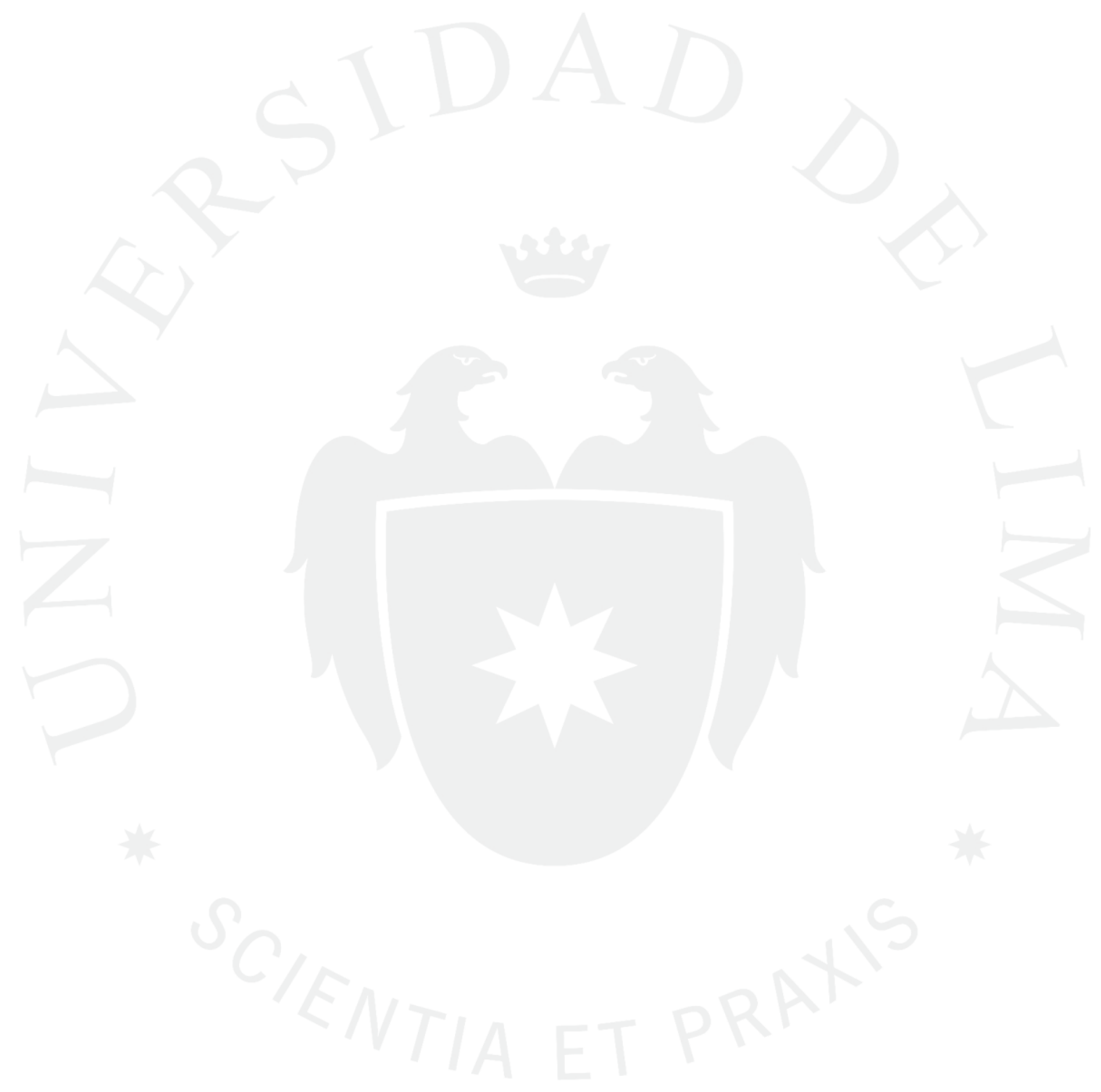




\section{CAPÍTULO 2: METODOLOGÍA}

Esta investigación se desarrolló mediante una metodología cualitativa, ya que se interpreta con diferentes técnicas el análisis de los contenidos presentados y se otorga la posibilidad de contextualización de los datos. Asimismo, es una investigación exploratoria porque, de un lado, provee de información referencial sobre un tema un tanto desconocido; por otro lado, es descriptiva en tanto profundiza busca reconocer elementos comunes en el corpus a partir de puntos de vista, opiniones y significados (Hernández Sampieri, Fernández Collado, \& Baptista Lucio, 2003).

Del mar de portadas publicadas por Caretas en los últimos diez años, se seleccionaron aquellas que habían empleado la técnica del montaje. De ese análisis se trabajó con una muestra representativa de cuatro portadas que tuvieron las siguientes características:

a. Comprometen a un actor político peruano,

b. Se relacionan con un acontecimiento de relevancia y repercusión sociales para el país en momentos de crisis política,

c. Los personajes involucrados forman o formaron parte de agrupaciones políticas que se vieron envueltas en la polémica producto de una mala gestión, cálculo político o errores de los cuales Caretas buscó, halló e hizo noticia de manera sarcástica,

d. En la construcción de la portada se utilizó el montaje de fotografías.

La unidad de análisis fue la portada de la revista y los elementos significativos (determinados a partir de las categorías e indicadores estudiados) de las informaciones relacionadas con la fotografía principal de las carátulas analizadas.

En las informaciones se aborda a cuatro personajes públicos que aparecen en las portadas seleccionadas: la lideresa del Partido Popular Cristiano, Lourdes Flores Nano (en el momento de las publicaciones, cabeza de la alianza Unidad Nacional para las elecciones del 2006); el expresidente Alberto Fujimori y su asesor, Vladimiro Montesinos (ambos presos acusados de una serie de delitos y sujetos de la noticia de los procesos judiciales que enfrentaron en el año 2007); Nadine Heredia de Humala, esposa del expresidente del Perú (en el período inicial del gobierno, cuando la primera dama ostentaba un alto nivel de aprobación en las encuestas incluso superior a la del mandatario); y el actual presidente Pedro Pablo Kuczynski (después de la primera vuelta electoral del 2016, cuando se vislumbraba como una sorpresa de los comicios de 
ese año frente a Keiko Fujimori). Ellos dieron origen a las siguientes carátulas:

a.“¿Entra?” (16 de marzo del 2006). Portada grafica a Lourdes Flores Nano, en ese entonces candidata a la presidencia del Perú. La noticia detrás es que necesitaba establecer reajustes dentro del Partido Popular Cristiana, en problemas graves que podrían dejar a la lideresa fuera de la competencia. Superados estos problemas, (Caretas, 2006). (Figura 1).

b.“Otra vez, ¿Amor sin Barreras?” (28 de diciembre del 2007). Portada grafica una vez más la relación sospechosa de Alberto Fujimori y Vladimiro Montesinos puesta en evidencia, nuevamente, durante el proceso judicial orientado a esclarecer los delitos cometidos durante el fujimorato. El expresidente, al ser interrogado por la justicia, se dedicó a alabar a su exasesor y cubrirle las espaldas para asegurar que este responda de la misma forma. (Caretas, 2007). (Figura 2).

"Lejos de embarrarlo, como pudo especularse en algún momento, Fujimori se cuidó de no pisar los superlativos callos de su ex asesor. Si en su alegato ante los tribunales chilenos Montesinos no existía, ahora era un coordinador eficaz, diligente y oportuno. Las corbatas de los siameses parecían reaparecer con intermitencia subliminal en la sétima audiencia en la que se buscó determinar la responsabilidad política de los mandos castrenses responsables de conducir la guerra interna. Para alguien tan poco dado a reconocer logros ajenos como Fujimori, las adulonas declaraciones parecen un mensaje para que Montesinos le pague con la misma moneda al momento de ser interrogado por la Corte y se enfrenten en histórico careo". (Caretas, 2007).

c. "Rosa de Espinas" (29 de agosto de 2012). Portada representa a la esposa del expresidente, Nadine Heredia, como Santa Rosa de Lima. Según la noticia, la primera dama era "la estable estampita de los altibajos de su marido". Hacía uso de su privilegiada posición y escogía bien sus actividades para mantener una agenda llena de quehaceres, saltar de avión en avión, figurar en las fotos y exhibir una buena imagen ante los peruanos. Según Caretas, en julio del 2012, las encuestas comprobaban su popularidad: $56 \%$ de aprobación. Por el contrario, Ollanta Humala tenía 36\%. (Caretas, 2012). (Figura 3). 
d."No es Broma" (21 de abril de 2016). Portada muestra la cabeza del actual presidente, Pedro Pablo Kuczynski, saliendo de una caja de sorpresas en carcajada batiente, después de la primera vuelta electoral y frente a los resultados de las encuestas que le daban por entonces una ventaja sobre Keiko Fujimori. (Caretas, 2016). (Figura 4).
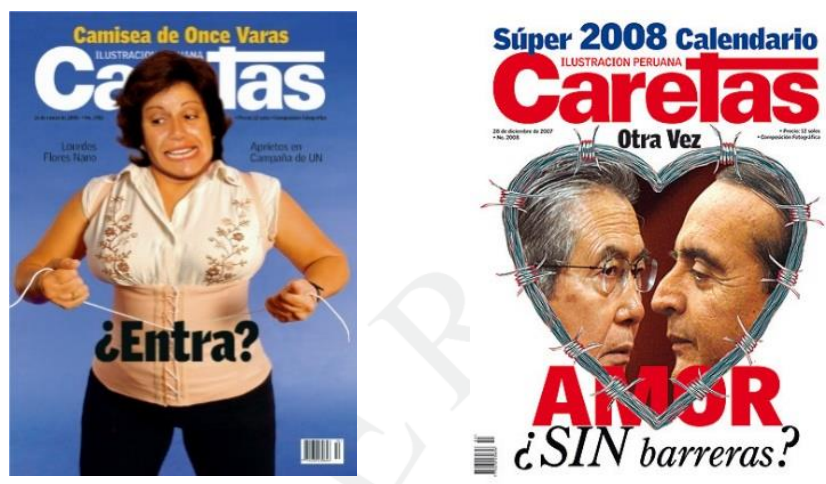

Figura 1. Lourdes. Figura 2. Fujimori y Montesinos.

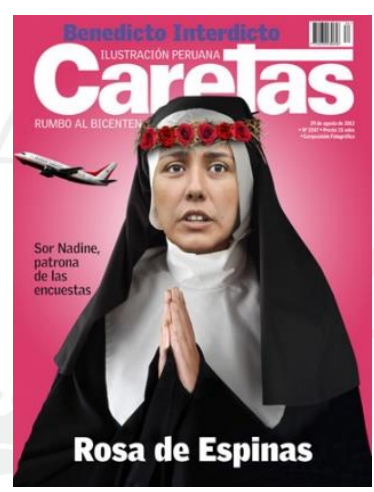

Figura 3. Nadine.

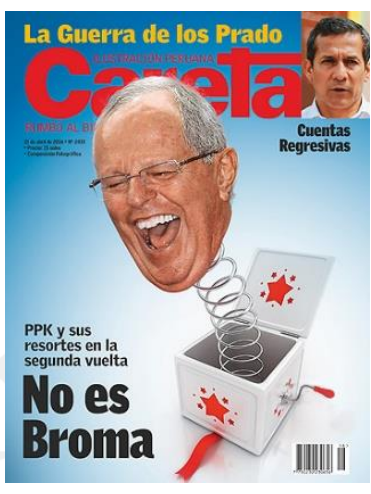

Figura 4. PPK.

Para la evaluación de esta muestra se utilizó como técnica de recolección de datos el modelo de análisis cualitativo de la narrativa propuesto por Antonio González García y Diego Caballo Ardila, así como la propuesta teórica de Gunther Kress, Regina LeiteGarcia y Theo van Leeuwen. Asimismo, se hizo un análisis de la imagen del político que se presenta en la revista, a través del modelo propuesto por David Berlo, James Lamert y Robert Metz.

Por otro lado, para conocer más de cerca las prácticas, hábitos y criterios periodísticos de Caretas para el proceso de publicación de su portada, se realizaron entrevistas a tres reporteros gráficos, dos de ellos salidos de las canteras de la revista.

En primer lugar, al actual jefe de fotografía, Víctor Ch. Vargas, reportero gráfico con más de 30 años en la revista y quien conoce la personalidad, las características y el valor diferencial de esta. También al destacado fotoperiodista Jaime Rázuri, egresado de la facultad de Comunicaciones de la Universidad de Lima y quien realizó especializaciones en fotografía y las perfeccionó en España; se inició como reportero gráfico en el diario La República, luego pasó por la revista Caretas y después por la agencia de noticias France Press. Ha incursionado en la fotografía documentalista tocando el tema del mestizaje, la cholificación, e incluso ha desarrollado un proyecto acerca de personas con VIH. Hizo coberturas en Irak, Haití y Palestina y es altamente reconoc 
ido debido a su labor durante el conflicto interno en el Perú en la década de 1980. Ha participado en exposiciones individuales y colectivas dentro del país y en el extranjero. Actualmente, es profesor de la Universidad de Lima y del Centro de la Imagen. También se entrevistó a Roberto Guerrero Espinoza, chileno de nacimiento, llegó en el 2000 al Perú y se nacionalizó peruano. Tiene más de 35 años en la carrera y ha trabajado para los diarios La Nación, Las Ultimas Noticias y La Tercera, de su país, así como en el diario peruano La República. Ha sido coordinador académico en Instituto Peruano de Arte y Diseño (IPAD) y luego pasó a formar parte de un proyecto de la comunidad cristiana del Movimiento Misionero Mundial. Actualmente, es reconocido por su libro fotográfico "Andahuaylazo: Crónica fotográfica de una asonada", el cual muestra 62 imágenes tomadas antes, durante y después del drástico suceso causado por Antauro Humala Tasso en enero del 2005. 


\section{CAPÍTULO 3: RESULTADOS}

\section{1 ¿Manipulación o montaje?}

Según la clasificación de Diego Caballo (2006), el montaje de Caretas se ajusta a diversas clasificaciones de manipulación fotográfica.

En primer lugar, con respecto al tipo de manipulación según el posible efecto en los receptores, la de Caretas sería una manipulación "de importancia media”, debido a que en la esquina superior derecha de cada portada se deja constancia de que se trata de una "composición fotográfica", con lo cual está advirtiendo al lector que la fotografía ha sido modificada o arreglada de manera que se pueda expresar el mensaje que ellos quieren transmitir de acuerdo a como ellos suelen hacerlo, es decir, con el montaje y la ilustración.

En segundo lugar, si se valora el tipo de manipulación según las motivaciones del emisor, estas portadas serían del tipo instrumental, ya que usualmente se eliminan partes de las fotografías tomadas a los políticos para favorecer el diseño el cual tienen pensado publicar y, por otro lado, también es de tipo humorístico y esto es más que evidente, ya que la esencia de esta revista es la burla, el sarcasmo y la sátira hacia temas políticos.

Según la técnica empleada, Caretas usa la inserción y la sustitución conjuntamente: por un lado, emplea la inserción de elementos gráficos como por ejemplo el corsé de Lourdes Flores, un corazón de espinas rodeando los rostros de Fujimori y Montesinos, la túnica de una monja en Nadine Heredia, la cabeza de Pedro Pablo Kuczynski en vez de la de un payaso de la caja de sorpresas; y, por otro lado, estos mismos elementos sirven como sustitución. Así, en los casos de Flores y Heredia, sus cuerpos son reemplazados por otros y al mismo tiempo presentados como los suyos.

\subsection{Fotografías y significaciones}

Con base en el análisis de González, y como todo texto periodístico, las portadas de Caretas connotan y denotan. Sin embargo, siguiendo el modelo de análisis del discurso de los cuatro cuadrantes que proponen Gunther Kress, Regina Leite-Garcia y Theo Van Leeuwen, las significaciones son múltiples si se toma en consideración la disposición de los elementos en la carátula. 


\subsection{1 “¿Entra?” o cómo sobrevivir en política}

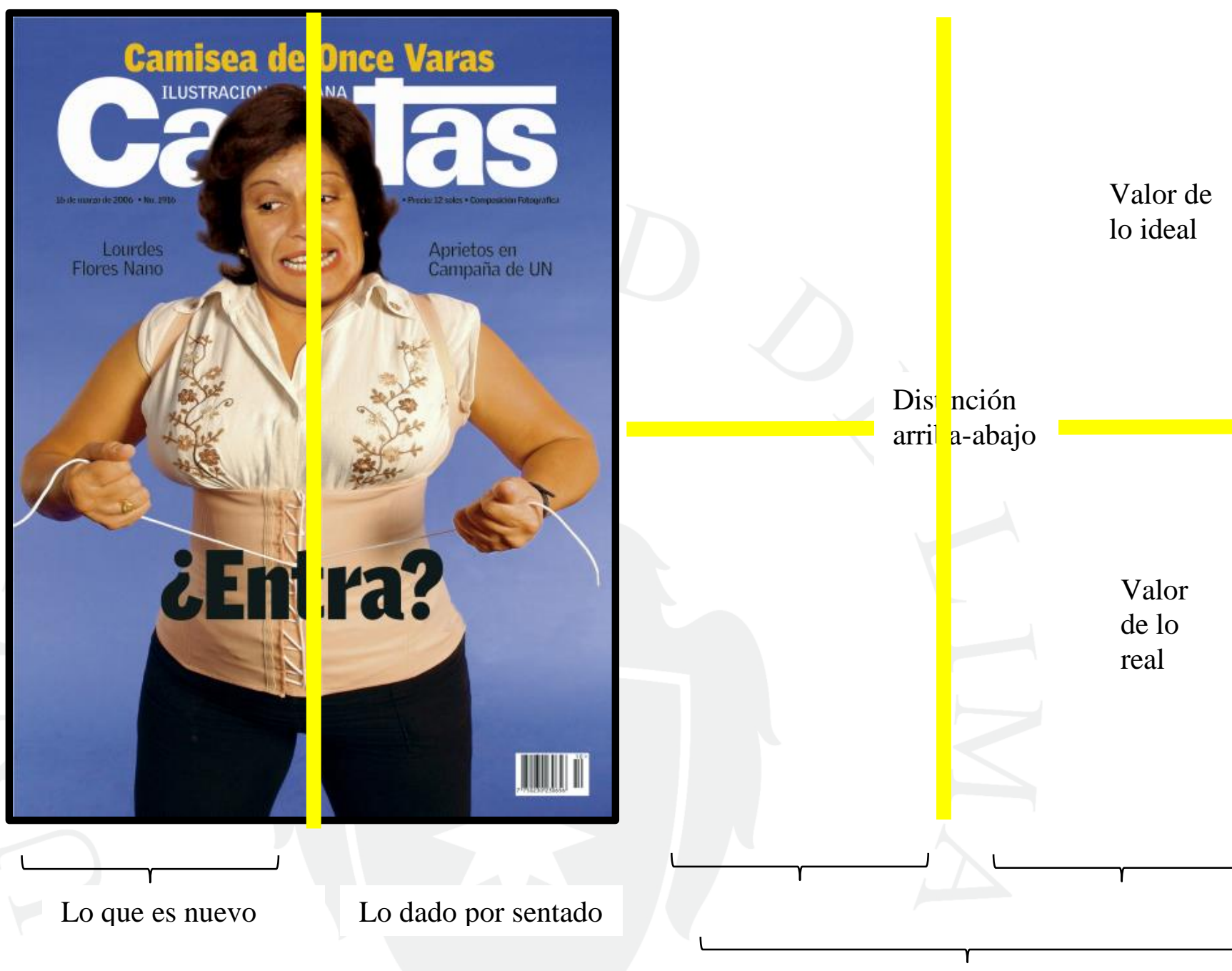

Distinción izquierda-derecha

Según Gunther Kress, Regina Leite-Garcia y Theo Van Leeuwen, el valor de "lo real", que se localiza en la sección inferior de la foto, viene a ubicarse desde el busto de Flores Nano hacia las piernas, lo cual indica que el corsé, las manos y el titular “Entra?” es lo que está aquí y ahora, lo presente. De estos elementos, el corsé es lo que primero llama la atención.

"Lo real” es que la excandidata se encontraba en aprietos en medio de una campaña con reveses en las encuestas y críticas internas al interior de la alianza Unidad Nacional, con la que participó en las elecciones. Integrada por los partidos PPC, Solidaridad Nacional, Renovación Nacional y Cambio Radical, la agrupación afrontó 
problemas y sus miembros tuvieron que amoldarse a la situación y encontrar soluciones rápidas como hacer menos mítines y hacer una campaña más cercana, más personal.

Asimismo, el detalle del corsé genera un segundo significado: más allá de su conocida contextura gruesa -que se vio alterada porque durante la campaña política Flores Nano se sometió a un riguroso régimen para bajar de peso-, lo que se quiere significar es que su campaña tuvo que pasar por un serio reajuste.

Por otro lado, en la parte superior está "lo ideal", lo distante en el tiempo, ya sea en el pasado o en el futuro. En este caso, vemos como principal elemento el rostro de Lourdes con un gesto forzado. Podemos decir que "lo ideal" en el futuro es que ya no existan estos problemas o aprietos que causen malestar, sino que finalmente ella pueda tener éxito en la campaña y salir electa, así como también pueda lograr estar en un peso promedio.

Con respecto a la distinción izquierda-derecha, no hay cambio: se muestra al lado izquierdo lo mismo que lo del lado derecho. Podríamos mirarlo como si fuera un espejo. Ya que el lado izquierdo es lo que conocemos o lo que se supone que es así y el lado derecho es lo que es nuevo, probablemente no existía nada nuevo para Lourdes Flores Nano y su partido, sino que todo seguirá igual. Evidentemente, lo que conocemos de ella es su trayectoria política y lo que había logrado hasta ese momento. Ha luchado mucho por tratar de obtener cargos políticos en el Perú como la alcaldía y la presidencia, pero en ambos casos, no ha tenido éxito alguno. Sabemos que tiene una personalidad fuerte y de poca empatía, y quizás debido a eso no ha podido ser aceptada por todo el pueblo. A su vez, se le ve como "la pobrecita" que no ha podido lograr nada. Por ende, todo lo que vendría a ser nuevo para ella no sería más que lo mismo de siempre, es decir, que ella no nos inspira expectativas de alguna novedad. Flores Nano perdió las elecciones por 60 mil votos o casi un punto y medio porcentual frente a Alan García, quien las derrotó por segunda vez como en el 2001. 


\subsection{2 “Otra vez, ¿Amor sin Barreras?” o la maquinación de dos mentes perversas}

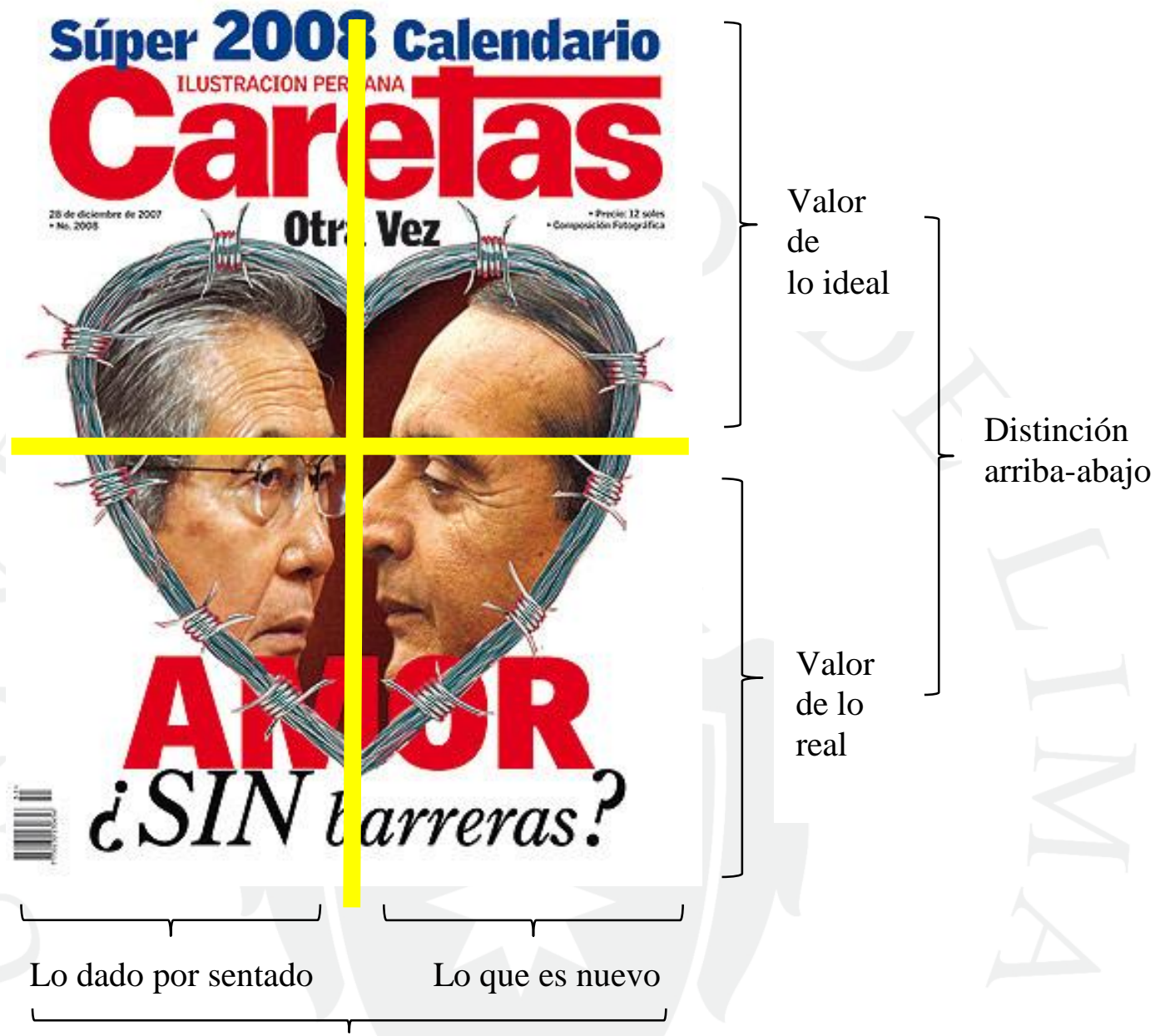

Distinción izquierda-derecha

La portada de Alberto Fujimori y Vladimiro Montesinos denota la relación de dos personajes cercanos, cuestionados y polémicos, unidos por los delitos que pesaron en su contra y que determinaron su carcelería.

Desde la perspectiva de González, la disposición de los elementos en la carátula es significativa. Las caras de ambos personajes, una frente a la otra, el corazón alrededor de ellos y el titular correspondiente, connotan una situación comprometedora, una relación íntima y bizarra al mismo tiempo. (Ver Anexo 1). Aunque no se miran directamente, la revista parece representar la intimidad entre dos personas, unidas por el amor (corazón) y el dolor (alambres de púas), durante un gobierno que ha generado estudios incluso de naturaleza psiquiátrica. (Nizama, 2008). 
En diciembre del 2007, se inició el megajuicio a Fujimori por los casos de Barrios Altos-La Cantuta y Sotanos del SIE lo cual generó expectativa respecto a que si el exmandatario excluiría a su exasesor como lo había hecho en sus primeras declaraciones a la justicia chilena. Fujimori y Montesinos se vieron las caras seis años después, en el 2014, durante una audiencia dentro del proceso judicial por la compra de los diarios chicha. Entonces, esta carátula de Caretas fue muy comentada porque durante la mencionada audiencia ambos personajes intercambiaron miradas de complicidad y el exasesor negó que su exjefe tuviera responsabilidad en los hechos. Para esa fecha, Fujimori había sido condenado a 25 años de prisión por la violación de derechos humanos.

Según Gunther Kress, Regina Leite-Garcia y Theo Van Leeuwen, el valor de "lo real" se revela en los cuadrantes inferiores: la frase "Amor sin Barreras" y la mayor parte de los rostros de Fujimori y Montesinos. Esto muestra algo conocido para todo el pueblo peruano: la estrecha vinculación del expresidente y su asesor durante sus diez años de gobierno, que el proceso judicial sacó a relucir. Después de ser descubierta la corrupción perpetrada durante el decenio fujimorista, la revista parece incidir en que, a pesar de haber sido procesados por la ley y rechazados por casi todo el país, ambos seguían protegiéndose ante graves acusaciones.

Dentro del valor de "lo ideal", aparece la frase "Otra Vez" y las frentes de los personajes. Parece que Caretas quisiera que el lector identifique la concurrencia de dos sujetos que quisieran, nuevamente, regresar al pasado; que desearían nunca haber sido descubiertos en los delitos que perpetraron; y que más bien el pueblo siga confiando en ellos. Aparecen como dos mentes que, idealmente, quisieran volver a maquinar para eludir la acción de la justicia; cosa que evidentemente no lograron.

Dentro de la distinción izquierda-derecha, aparece el rostro de Fujimori como lo conocido, lo que nos fue dado, es decir, la gestión de gobierno, en lo positivo y en lo negativo. En el lado derecho, el rostro de Montesinos, representa lo desconocido del mismo régimen, pero que fue descubierto gracias a los "vladivideos": la corrupción, el ilegal manejo del dinero público desembolsado para pagar sobornos, asesinatos y otras violaciones que trajeron consigo el deshonor, la traición y la desconfianza del fujimorato. 


\subsection{3 "Rosa de Espinas" o una falsa santa}

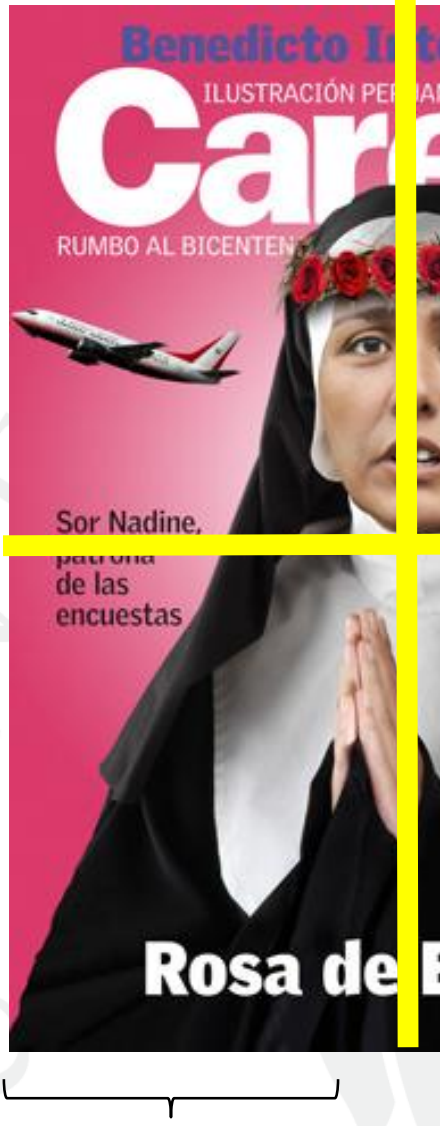

Lo dado por sentado
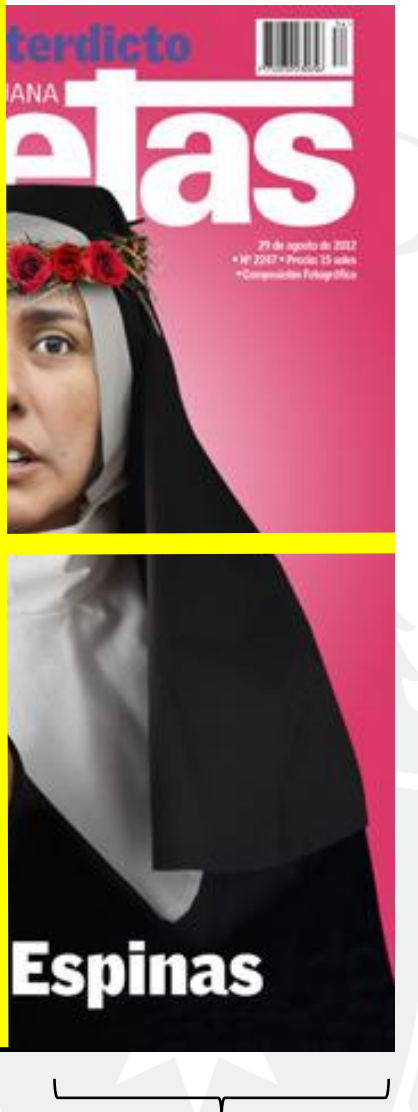

Lo que es nuevo

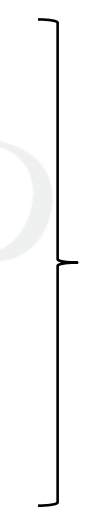

Valor

de lo ideal

Distinción arribaabajo
Valor de lo real

Distinción izquierda-derecha

La portada de Nadine Heredia es un poco más compleja respecto a lo que denota y connota. La representación de la primera dama, acorde la propuesta de González, es la de una mujer de fe, de la más santa de las santas: como Santa Rosa de Lima.

A diferencia de la corona de rosas con que se suele representar a Santa Rosa, la de Nadine Heredia también tiene espinas. La revista connota que, a pesar de mostrarse como una mujer sacrificada, poderosa y que realizaba gestiones a favor del pueblo, tenía un lado impostor, aprovechador o doble cara cuando hacía excesivo uso de sus privilegios, se relacionaba con ciertas personas por interés y asumía responsabilidades 
que no le correspondían. Esta situación lejos de afectar su popularidad, la incrementaba; pero Caretas no le cree. (Ver Anexo 1).

El valor de "lo real" se define con la frase "Sor Nadine, patrona de las encuestas". La 'santidad' de una mujer que solo quiere lo mejor para el país y que su interés siempre está puesto en Perú y en su gente. Por ende, el pueblo la acepta, la quiere y ella tiene la seguridad de que es la preferida porque las encuestas así lo dicen. Sin embargo, desde la perspectiva de Caretas, la otra realidad revelada en el título el título "Rosa de Espinas" que contradice con sarcasmo a la mujer que ora. La revista no cree en la 'cara buena' ni en nada de lo que ella pueda hacer.

Dentro de "lo ideal", vemos un avión y una corona de espinas sobre su cabeza, ambos elementos son parte de lo que está distante en el tiempo, ya sea en el pasado o en el futuro. Es decir, "lo ideal" para Nadine es seguir siendo la preferida del pueblo, tomar posición y abarcar responsabilidades en la Presidencia.

En la izquierda, en el ámbito de lo conocido, aparece el avión presidencial, sus viajes al exterior, las obras benéficas del Gobierno y de la primera dama. En la derecha no hay nada especial, aplicando la propuesta de Gunther Kress, Regina Leite-Garcia y Theo Van Leeuwen.

\subsection{4 "No es broma" o el presagio del éxito político}

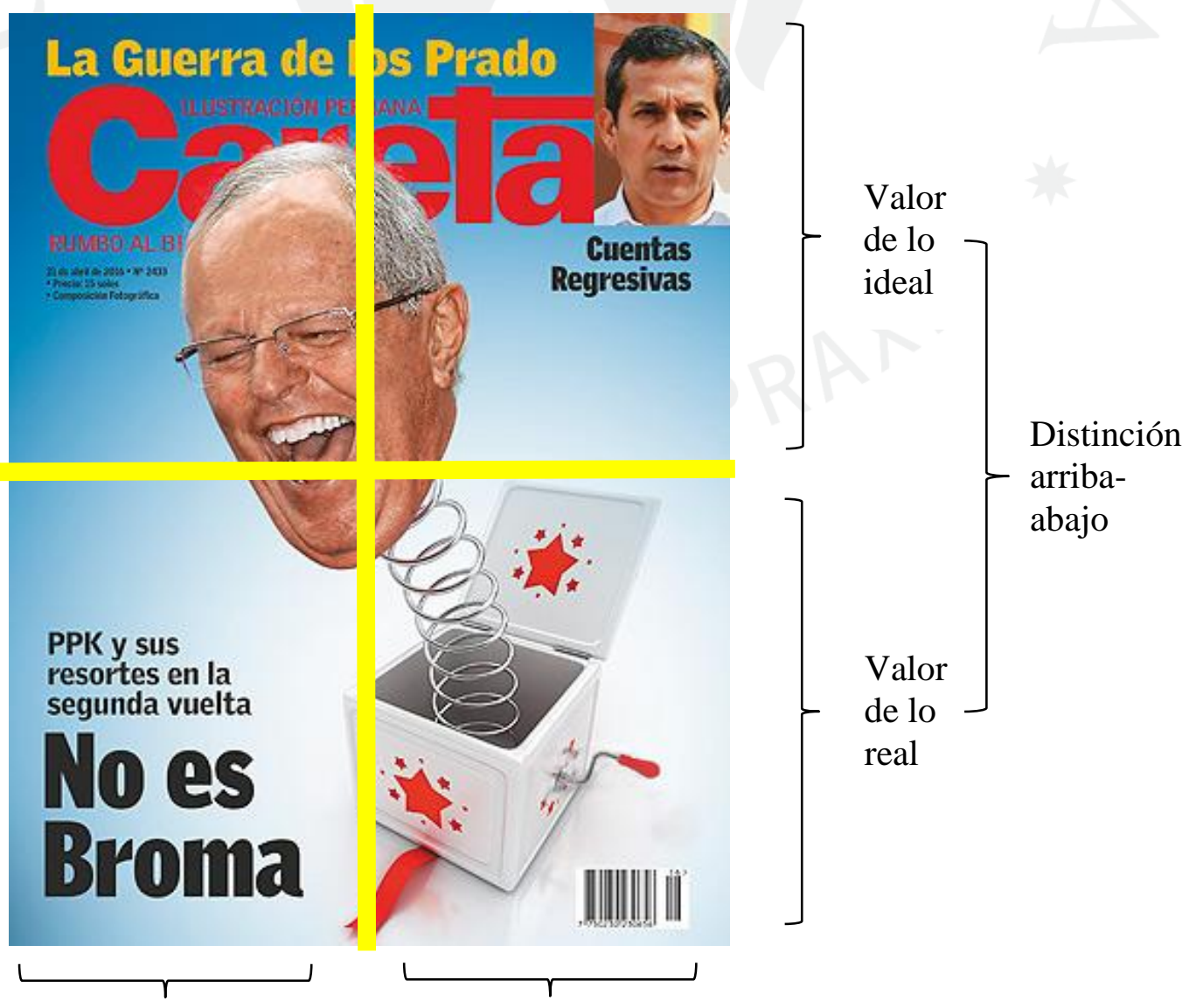


Distinción izquierda-derecha de Pedro Pablo Kuczynski denota al candidato que, tras la primera vuelta, ríe a carcajadas. Y no es para menos: ha saltado a la segunda vuelta incluso para sorpresa de aquellos escépticos que lo consideraron un personaje simpático, pero sin mayores opciones durante gran parte de la campaña.

La representación de la caja de sorpresas, de las cual suele surgir un payaso, no ridiculiza al personaje, como suele pasar con las demás 'víctimas' de Caretas. En este caso, va de acuerdo con la personalidad de PPK y su campaña política, la cual fue llevada a cabo de una manera jovial, divertida y humorística. (Ver Anexo 1).

Dentro del valor de "lo ideal", según Gunther Kress, Regina Leite-Garcia y Theo Van Leeuwen, se encuentra el rostro de Kuczynski carcajeándose a más no poder. Esto hace representación de un político que en el pasado como en el presente, y posiblemente, también en el futuro, siempre ha desarrollado una imagen de acercamiento semejante a la de un abuelo que actúa como joven y es amigo de todos. Para entonces, los resultados de las encuestas después de la primera vuelta (44\% de PPK y $40 \%$ de Keiko Fujimori, según Ipsos Perú), fueron interpretadas por la revista como una buena señal de que el popular PPK podría llegar a la Presidencia de la República frente a la favorita.

Dentro del valor de "lo real", se encuentra la caja de sorpresas que, según la teoría aplicada, es lo que sucede aquí y ahora. Según la noticia, el candidato comenzaba a perfilarse como una sorpresa y como tal aparece como el candidato inesperado.

Con respecto a la distinción del lado izquierdo, tenemos el título de la portada "No es Broma" y el rostro feliz de PPK. Esto podría interpretarse como una contradicción: no es broma y PPK puede ganar, pero ni siquiera el candidato lo cree. $\mathrm{O}$ PPK puede ganar y el candidato ha comenzado a celebrar.

En la distinción de la derecha tenemos nuevamente la caja de sorpresas, pero en este caso, con el significado de la teoría que sería "lo que es nuevo". Obtendríamos el mismo significado de "lo real": la subida de PPK en las encuestas es una noticia inesperada para todos, para el pueblo e incluso para los dos candidatos a la presidencia. 


\subsection{Una imagen del líder político}

¿Cuál es la imagen de los líderes políticos después de exponerse a los montajes de Caretas?

Aplicando el modelo de análisis propuesto por David Berlo, James Lamert y Robert Metz, podría decirse que Lourdes Flores Nano no reúne ninguna de las características exigidas en un político. Su baja aceptación en el electorado habla de una escasa identificación con la lideresa. Solo se le reconoce en la categoría de la "similitud", puede ser una de nosotros, pero además es una perdedora a quien se comprende. La empatía proviene de la lástima hacia una política que intentó infructuosamente ganar la más alta investidura en varias ocasiones sin éxito.

Portada de Lourdes

\begin{tabular}{l|l}
\hline Atribuciones o características & $\mathrm{X}(\mathrm{si})$ \\
\hline Competencia & \\
Fiabilidad ética & $\mathrm{X}$ \\
Dinamismo & \\
Similitud & \\
Proximidad & \\
Agrado & \\
Control y administración de castigos y premios & \\
Interés en la opinión pública del receptor & \\
Control de desviaciones & \\
\hline
\end{tabular}

Tabla 3. Los componentes de la imagen que se reconstruye de Lourdes Flores.

El caso de la portada de Alberto Fujimori y Vladimiro Montesinos es más grave, pues ambos personajes políticos carecen de toda atribución o característica reconocida y reconocible. Detrás de ellos guarece una historia de corrupción y la imagen solo ratifica más información que apoya esa mala imagen; imagen que tiene la mayoría de peruanos que sabe lo malo que le hicieron y a los que no se puede tolerar más.

\begin{tabular}{ll}
\hline Portada de Fujimori y Montesinos \\
\hline Atribuciones o características
\end{tabular}




\section{Competencia}

Fiabilidad ética

Dinamismo

Similitud

Proximidad

Agrado

Control y administración de castigos y premios

Interés en la opinión pública del receptor

Control de desviaciones

Tabla 4. Los componentes de la imagen que se reconstruye de Fujimori y Montesinos.

En la portada de Nadine Heredia, el personaje exhibe un nivel de aceptación mayor. En primer lugar, cuenta con la fiabilidad ética, muchas personas confiaban en ella, la veían como la justiciera del pueblo. A pesar de que desde el inicio del mandato de su esposo la prensa destacó la imagen sarcástica de la primera dama, en Caretas se la ve como una "santa", una persona correcta.

En segundo lugar, hay proximidad, es decir, el pueblo la siente cercana a él; a pesar de la posición de poder que ella ostentaba en ese momento, no es distinta a los otros, sino su representante.

En tercer lugar, está el agrado: Heredia muestra un buen trato, es amable y agradable. La imagen muestra a un personaje interesado en el pueblo y en la opinión pública: ella sabe tomar decisiones, vela por el bien del pueblo y recoge sus opiniones.

\begin{tabular}{ll}
\hline Portada de Nadine & \\
\hline Atribuciones o características & $\mathrm{X}(\mathrm{si})$ \\
\hline Competencia & $\mathrm{X}$ \\
Fiabilidad ética & \\
Dinamismo & \\
Similitud & $\mathrm{X}$ \\
Proximidad & $\mathrm{X}$ \\
Agrado & $\mathrm{y}$
\end{tabular}


premios

Interés en la opinión pública del receptor $\quad \mathrm{X}$

Control de desviaciones

Tabla 5. Los componentes de la imagen que se reconstruye de Nadine.

La portada de Pedro Pablo Kuczynski ofrece dinamismo. A pesar de que el entonces candidato era una persona de avanzada edad, está siempre presente y actualizado en todo, especialmente con los jóvenes. También está la proximidad, en donde se demuestra que PPK está cerca al pueblo peruano por las últimas aprobaciones que tuvo en las encuestas para las elecciones. Asimismo, es agradable a las personas, por el hecho de que está siempre alegre, bromeando y manteniendo una actitud siempre positiva. Mantiene el interés de la opinión pública; presta atención a las necesidades de las personas y a las opiniones de los jóvenes para poder tomar decisiones respecto a ellos.

\begin{tabular}{ll}
\hline Portada de PPK & \\
\hline Atribuciones o características & $\mathrm{X}(\mathrm{si})$ \\
\hline Competencia & \\
Fiabilidad ética & $\mathrm{X}$ \\
Dinamismo & \\
Similitud & $\mathrm{X}$ \\
Proximidad & $\mathrm{X}$ \\
Agrado & \\
Control y administración de castigos & $\mathrm{y}$ \\
premios & $\mathrm{X}$ \\
Interés en la opinión pública del receptor & \\
Control de desviaciones & \\
\hline
\end{tabular}

Tabla 6. Los componentes de la imagen que se reconstruye de PPK.

\subsection{Una explicación de las líneas editoriales}

Las entrevistas con reporteros gráficos vinculados directa o indirectamente con la revista Caretas permitió recoger sus puntos de vistas sobre el tratamiento que la 
publicación ha dado históricamente a la fotografía periodística, vinculado a su línea editorial.

Para el jefe de fotografía, Víctor Chacón Vargas, Caretas es una revista que conoce muy bien la personalidad que tiene y se sabe de un estilo único en el país. Dentro de ese estilo, la publicación considera que su trabajo fotográfico no es manipulación sino un montaje que se ajusta a los cánones que permite el fotoperiodismo.

Los reporteros gráficos Jaime Rázuri y Roberto Guerrero coinciden con esta percepción, aunque sus posiciones sobre cuándo procede la manipulación es diferente.

Rázuri afirmó que los retoques que hace un medio de prensa se ajustan a sus líneas editoriales, cada manipulación corresponderá a los cánones y necesidades que tenga la publicación porque, al fin y al cabo, cada una tiene un público objetivo al cual llegar que de alguna manera conoce esos parámetros. En el caso de Caretas, tiene un público acostumbrado a este tipo de fotomontajes desde hace muchos años (ver Anexo $3)$.

Guerrero mencionó que Caretas manipula por medio del juego con los personajes, es decir, reconoce las creaciones de esta revista como parte de lo que es la manipulación, Sin embargo, según él, esto es válido siempre y cuando se advierta sobre la situación, ya que, en caso contrario, perdería la credibilidad de los lectores.

Para Rázuri, la manipulación es admisible en casos que así lo demande la publicación, en otras palabras, en aras de la calidad, se puede alterar una foto. Guerrero por su parte sostuvo que en ningún caso se justifica hacer uso de ella.

\begin{tabular}{|c|c|c|c|}
\hline $\begin{array}{l}\text { Preguntas } \\
\text { /Entrevistado }\end{array}$ & Víctor Ch. Vargas & Jaime Rázuri & Roberto Guerrero \\
\hline $\begin{array}{l}\text { Opinión sobre } \\
\text { la } \\
\text { manipulación }\end{array}$ & $\begin{array}{l}\text { Manipulación en prensa } \\
\text { no debe existir. A veces } \\
\text { uno lo ve en periódicos y } \\
\text { se da cuenta, pero no se } \\
\text { debe hacer. Si se }\end{array}$ & $\begin{array}{l}\text { Si por la manipulación } \\
\text { digital te refieres a la } \\
\text { alteración de una } \\
\text { imagen y que eso no } \\
\text { corresponde a una }\end{array}$ & 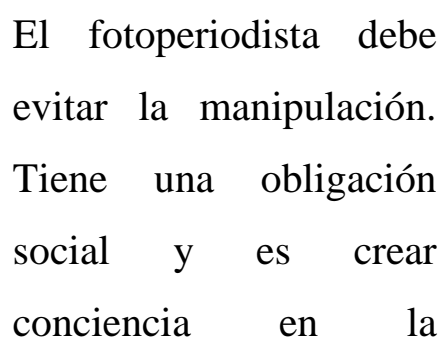 \\
\hline
\end{tabular}




\begin{tabular}{|c|c|c|c|}
\hline & manipula, es engaño. & $\begin{array}{l}\text { situación informativa, } \\
\text { entonces no estoy de } \\
\text { acuerdo, pero si te } \\
\text { refieres a hacer } \\
\text { correcciones básicas y } \\
\text { elementales, obvio que } \\
\text { si es más que } \\
\text { necesario. }\end{array}$ & $\begin{array}{l}\text { sociedad. Es el nexo } \\
\text { entre los hechos y los } \\
\text { lectores. Ese nexo debe } \\
\text { ser lo más objetivo } \\
\text { posible. }\end{array}$ \\
\hline $\begin{array}{l}\text { Casos de } \\
\text { manipulación } \\
\text { en otros } \\
\text { medios }\end{array}$ & $\begin{array}{l}\text { Cuando toman una foto } \\
\text { en la cancha al arquero y } \\
\text { la pelota está ahí en la } \\
\text { foto, pero es mentira. La } \\
\text { pelota la han puesto } \\
\text { porque no la agarraron en } \\
\text { el encuadre. }\end{array}$ & $\begin{array}{l}\text { He visto } \\
\text { manipulaciones } \\
\text { burdas. La última que } \\
\text { circuló fue la foto de } \\
\text { Castañeda chequeando } \\
\text { unas obras de un túnel, } \\
\text { pero en realidad nunca } \\
\text { estuvo ahí, sino que lo } \\
\text { pastearon en la } \\
\text { imagen. }\end{array}$ & $\begin{array}{l}\text { En el caso de Caretas, } \\
\text { que juega con } \\
\text { personajes, va con un } \\
\text { crédito que dice que } \\
\text { hicieron } \\
\text { manipulación. Eso si es } \\
\text { permitido, porque tiene } \\
\text { esa línea de burlarse a } \\
\text { través de la imagen y } \\
\text { porque el medio dice que } \\
\text { es un truco. }\end{array}$ \\
\hline $\begin{array}{l}\text { Qué hacer en } \\
\text { caso de que } \\
\text { un medio de } \\
\text { prensa haga } \\
\text { una } \\
\text { manipulación }\end{array}$ & & $\begin{array}{l}\text { Hacerlo público. Es la } \\
\text { única manera que tiene } \\
\text { la sociedad de } \\
\text { corregirse a sí misma. } \\
\text { Corregir las } \\
\text { instituciones a las que } \\
\text { supuestamente se les } \\
\text { está otorgando un } \\
\text { nivel de fiabilidad y de } \\
\text { credibilidad. }\end{array}$ & $\begin{array}{l}\text { Desgraciadamente, la } \\
\text { sociedad no es crítica } \\
\text { con los medios de } \\
\text { comunicación. Somos } \\
\text { muy suaves al momento } \\
\text { de ser lectores. Al } \\
\text { manipular una foto nos } \\
\text { están manipulando como } \\
\text { lectores con fotografías } \\
\text { trabajadas. }\end{array}$ \\
\hline $\begin{array}{l}\text { Qué no se } \\
\text { debe hacer }\end{array}$ & & $\begin{array}{l}\text { Colocar elementos } \\
\text { donde no los hubo o } \\
\text { que un rostro esté }\end{array}$ & $\begin{array}{l}\text { Lo más que se puede } \\
\text { hacer es limpiar. Darle el } \\
\text { contraste mínimo que }\end{array}$ \\
\hline
\end{tabular}




\begin{tabular}{|c|c|c|c|}
\hline & & $\begin{array}{l}\text { demacrado y que } \\
\text { finalmente se muestre } \\
\text { como algo que no } \\
\text { estuvo demacrado. }\end{array}$ & $\begin{array}{l}\text { necesita, pero no puede } \\
\text { alterar } \\
\text { composición } \\
\text { encuadres. }\end{array}$ \\
\hline
\end{tabular}




\section{CONCLUSIONES}

El fotoperiodismo plantea unos límites éticos y tecnológicos que, como señala esta investigación, deberían ser entendidos y aplicados incluso por publicaciones que utilizan el montaje periodístico abierta y explícitamente.

En el caso de las portadas de Caretas se puede concluir que, si bien el montaje que realiza muestra características de manipulación fotográfica, se trata de una actividad que no viola principios elementales de veracidad y credibilidad. Se trata más bien de un ejercicio conocido, pactado no solo con el público lector, que es alertado sobre los cambios premeditados hechos a la imagen, sino también con los políticos que frecuentemente aparecen en el espacio (no se conoce de demandas o quejas contra los montajes que los involucran). Por ello, los fotoperiodistas Víctor Chacón Vargas, Jaime Rázuri y Roberto Guerrero coinciden en que esta práctica no es manipulación, sino una parte del ADN de la revista; que es su naturaleza y el público lo sabe.

Todos aceptan los objetivos de la manipulación técnica aplica, saben cuál es su objetivo y la función del estilo político, de humor y sarcasmo de Caretas.

Lo que sí resulta desconocido para públicos y actores protagonistas son las significaciones que el Photoshop puede generar, y hacia ellas va nuestro análisis. En los cuatro casos revisados, las portadas siempre denotan y connotan más de un sentido, es decir, muestran algo escondido que lleva a un segundo mensaje producido por la composición gráfica que se hace de los elementos (posición arriba, abajo, izquierda o derecha de la carátula).

Los protagonistas de la noticia son sometidos a una evaluación pública, una suerte de comparación entre sus vidas presentes y pasadas, entre su quehacer actual y el interés público. Se presentan sus debilidades de manera denotativa, para connotar un quehacer por lo general defectuoso en la práctica de hacer política.

El peso simbólico de la portada no sería el mismo sin los titulares y objetos que acompañan a la imagen. Todos contribuyen a la ironía, el sarcasmo y la burla; a colocar en ridículo al personaje, sea por la inserción de un cuerpo que no pertenece al original o por la posición del rostro que deja a la persona en una situación incómoda o vergonzosa. 
Caretas no cuenta la noticia de manera directa como suelen hacerlo otros medios de prensa, sino que la fotografía en su portada, ya sea recortada o completa, y los elementos que la complementan (titulares y objetos), obligan a una lectura más profunda para entender de lo que se está hablando.

Aunque este no es un análisis de los públicos, puede estimarse que las portadas de Caretas exigen experiencia por parte de lector para entender el estilo de la revista, su lenguaje y los usos dados a las formas gráficas. En segundo lugar, también les demandará conocimiento de la realidad política del país, es decir, estar en contexto y actualizado con la historia detrás de la noticia; de lo contrario, el mensaje satírico y humorístico no se entenderá. Si como señalan las teorías de comunicación, los medios no cambian posiciones, sino que ratifican actitudes, también podría suponerse que los lectores de Caretas son personas que concuerdan con la portada y por eso compran la revista.

Cuando esta investigación se inició, partió del supuesto de que la manipulación fotográfica es inadmisible, así como la tergiversación malintencionada de colores, composición, encuadre e iluminación de la fotografía (ALOJ, 2015). Cuando el fotoperiodismo solo busca es afectar solamente la credibilidad per se de los actores sociales (Caballo, 2006).

Por ello coincidimos en que las prácticas de Caretas, diestra en el fotomontaje casi desde su fundación, no es vejatoria ni ideológica ni pone en riesgo la calidad informativa. Tras el afán estético e instrumental, prevalece un estilo libre e irreverente que cuida los entretelones de la noticia y confía en la complicidad del lector. 


\section{REFERENCIAS}

ALOJ. (10 de Mayo de 2015). Obtenido de

http://www.aloj.us.es/galba/digital/cuatrimestre_ii/imagen-

pagina/analisis_imagen.htm

Asociación Nacional de Fotoperiodistas de Inglaterra. (20 de Octubre de 2012). NPPA.

Obtenido de The Voice of Visual Journalists: https://nppa.org/page/631

Caballo, A. D. (2006). Fotoperiodismo y Edición. Madrid: Universitas.

Cabanillas, Y. (2016). Imagen política de Ollanta Humala en las campañas electorales 2006-2011. Redalyc(11), 179-190. Obtenido de

http://www.redalyc.org/html/310/31048902012/

Caretas. (16 de Marzo de 2006). Curvas Borrascosas. Lima, Lima, Perú: Caretas.

Recuperado el 4 de Febrero de 2017, de

http://www2.caretas.pe/Main.asp?T=3082\&S=\&id=12\&idE=663\&idSTo=0\&id A=19345\#.WKItWYErIdU

Caretas. (28 de Diciembre de 2007). El Retorno del Siamés. Lima, Lima, Perú: Caretas. Recuperado el 4 de Febrero de 2017, de http://www2.caretas.pe/Main.asp?T=3082\&S=\&id=12\&idE=757\&idSTo=0\&id $\mathrm{A}=30550 \#$.Wd_u92jWxPZ

Caretas. (29 de Agosto de 2012). La Primera Dama en la Cresta de La Ola. Lima,

Lima, Perú: Caretas. Recuperado el 4 de Febrero de 2017, de

http://www2.caretas.pe/Main.asp?T=3082\&S=\&id=12\&idE=1057\&idSTo=0\&i $\mathrm{dA}=60631 \#$.WKIuqoErIdU

Caretas. (21 de Abril de 2016). En la Cocina de PPK. Lima, Lima, Perú: Caretas.

Recuperado el 4 de Febrero de 2017, de

http://www2.caretas.pe/Main.asp?T=3082\&S=\&id=12\&idE=1256\&idSTo=0\&i

$\mathrm{dA}=75266 \#$.WKN9o4ErIdU

Doménech, F. H. (2013). La Manipulación de la Imagen Informativa. Retos y

Oportunidades para el Fotoperiodismo en el Contexto Digital. Sphera Publica, 106-123.

Hernández Sampieri, R., Fernández Collado, C., \& Baptista Lucio, P. (2003).

Metodología de la Investigación. México D. F. : Mcgraw-Hill.

Hernández, G. I. (2003). Estética de la Habilidad y Nuevas Tecnologías. Bogotá: Centro Editorial Javeriano.

Kress, G., Leite-García, R., \& Van Leeuwen, T. (2010). El Discurso como Estructura y Proceso. Barcelona: Gedisa.

Maciá, B. C. (2002). Tecnología y Manipulación en la Fotografía de Prensa. En C. P. Amador, A. J. Robledano , \& F. M. Ruiz (Edits.), Tratamiento Digital de la Imagen (págs. 143-152). Madrid: Universidad Carlos III.

Nizama, M. (2008). Psicopatía política: Caso Fujimori. Revista IIPSI, 11(1), 11-36.

Puémape, F. (2014). La poca competitividad de los partidos políticos peruanos. El caso del Partido Popular Cristiano (PPC). Revista de Ciencia Política y Gobierno, l(2), 157-182. 
ANEXOS 


\section{ANEXO 1: CUADRO COMPARATIVO DE PORTADAS}

\begin{tabular}{|c|c|c|c|c|}
\hline & $\begin{array}{l}\text { Portada } \\
\text { Flores Nano }\end{array}$ & $\begin{array}{l}\text { Portada Fujimori } \\
\text { y Montesinos }\end{array}$ & Portada Heredia & Portada Kuczynski \\
\hline $\begin{array}{l}\text { Textos y } \\
\text { titulares } \\
\text { que la } \\
\text { acompañan }\end{array}$ & $\begin{array}{l}\text { ¿Entra? } \\
\text { Lourdes Flores } \\
\text { Nano } \\
\text { Aprietos en } \\
\text { campaña de UN }\end{array}$ & $\begin{array}{l}\text { Otra Vez } \\
\text { ¿Amor Sin } \\
\text { Barreras? }\end{array}$ & $\begin{array}{l}\text { Rosa de Espinas } \\
\text { Sor Nadine, patrona } \\
\text { de las encuestas }\end{array}$ & $\begin{array}{l}\text { No es Broma } \\
\text { PPK y sus resortes en } \\
\text { la segunda vuelta }\end{array}$ \\
\hline Montaje & $\begin{array}{l}\text { Rostro montado } \\
\text { en el cuerpo }\end{array}$ & $\begin{array}{l}\text { Un rostro al lado de } \\
\text { otro con un corazón } \\
\text { alrededor }\end{array}$ & $\begin{array}{l}\text { Rostro montado en } \\
\text { el cuerpo y una } \\
\text { corona de espinas } \\
\text { encima }\end{array}$ & $\begin{array}{l}\text { Rostro montado en un } \\
\text { resorte de una caja de } \\
\text { sorpresas }\end{array}$ \\
\hline $\begin{array}{l}\text { Recorrido } \\
\text { visual }\end{array}$ & $\begin{array}{l}\text { Corsé, manos, } \\
\text { rostro, texto }\end{array}$ & $\begin{array}{l}\text { Texto, miradas, } \\
\text { corazón }\end{array}$ & $\begin{array}{l}\text { Rostro, corona de } \\
\text { espinas, manos, } \\
\text { avión, texto }\end{array}$ & $\begin{array}{l}\text { Rostro, resorte, caja, } \\
\text { título }\end{array}$ \\
\hline Denotación & $\begin{array}{l}\text { Lourdes } \\
\text { ajustándose el } \\
\text { corsé lo más que } \\
\text { pueda }\end{array}$ & $\begin{array}{l}\text { A Fujimori y } \\
\text { Montesinos los } \\
\text { encierra un corazón } \\
\text { hecho de alambres }\end{array}$ & $\begin{array}{l}\text { Nadine Heredia es } \\
\text { una monja con una } \\
\text { corona de espinas }\end{array}$ & $\begin{array}{l}\text { Kuczynski } \\
\text { explotando y } \\
\text { rebotando de } \\
\text { felicidad }\end{array}$ \\
\hline $\begin{array}{l}\text { ¿Quién } \\
\text { representa? }\end{array}$ & Lourdes & $\begin{array}{l}\text { Fujimori y } \\
\text { Montesinos }\end{array}$ & Nadine & PPK \\
\hline $\begin{array}{l}\text { ¿Que } \\
\text { representa? }\end{array}$ & $\begin{array}{l}\text { Que quiere verse } \\
\text { más delgada }\end{array}$ & $\begin{array}{l}\text { La intimidad } \\
\text { accidentada que } \\
\text { existe entre ellos }\end{array}$ & $\begin{array}{l}\text { Santidad, que hace } \\
\text { cosas buenas, pero } \\
\text { que hay un lado no } \\
\text { conocido }\end{array}$ & $\begin{array}{l}\text { Que está muy } \\
\text { contento porque algo } \\
\text { bueno ocurrió }\end{array}$ \\
\hline $\begin{array}{l}\text { ¿Cómo lo } \\
\text { representa? }\end{array}$ & $\begin{array}{l}\text { Ajustando un } \\
\text { corsé en su torso }\end{array}$ & $\begin{array}{l}\text { Con el corazón } \\
\text { alrededor y las } \\
\text { miradas muy } \\
\text { cercanas }\end{array}$ & $\begin{array}{l}\text { Vestida de monja y } \\
\text { una corona encima }\end{array}$ & $\begin{array}{l}\text { Saliendo feliz de una } \\
\text { caja de sorpresas } \\
\text { colorida }\end{array}$ \\
\hline $\begin{array}{l}\text { ¿Por qué lo } \\
\text { representa así? }\end{array}$ & $\begin{array}{l}\text { Porque un corsé } \\
\text { hace que el } \\
\text { cuerpo se ajuste } \\
\text { y se estilice }\end{array}$ & $\begin{array}{l}\text { Porque el corazón } \\
\text { es el símbolo del } \\
\text { amor y los alambres } \\
\text { con púas son } \\
\text { símbolo de dolor }\end{array}$ & $\begin{array}{l}\text { Porque el traje de } \\
\text { monja representa la } \\
\text { bondad, pero la } \\
\text { corona de espinas } \\
\text { representa pasión }\end{array}$ & $\begin{array}{l}\text { Porque la caja de } \\
\text { sorpresas representa } \\
\text { algo que surge } \\
\text { inesperadamente de } \\
\text { un momento a otro }\end{array}$ \\
\hline $\begin{array}{l}\text { ¿Para qué lo } \\
\text { representa? }\end{array}$ & $\begin{array}{l}\text { Para verse más } \\
\text { delgada }\end{array}$ & $\begin{array}{l}\text { Para remarcar la } \\
\text { confianza mutua }\end{array}$ & Para caer bien & $\begin{array}{l}\text { Para anunciar la } \\
\text { sorpresa inesperada }\end{array}$ \\
\hline
\end{tabular}




\begin{tabular}{|c|c|c|c|c|}
\hline Objetos & Corsé & $\begin{array}{l}\text { Corazón hecho de } \\
\text { alambres }\end{array}$ & $\begin{array}{l}\text { Corona de espinas, } \\
\text { avión }\end{array}$ & Caja de sorpresas \\
\hline Connotación & $\begin{array}{l}\text { Así como } \\
\text { Lourdes ajusta su } \\
\text { cuerpo para } \\
\text { poder verse más } \\
\text { delgada y entrar } \\
\text { en el molde, el } \\
\text { corsé también } \\
\text { significa que ella } \\
\text { hace cambios de } \\
\text { urgencia en la } \\
\text { campaña y ajusta } \\
\text { todo en la UN } \\
\text { para ganar las } \\
\text { elecciones }\end{array}$ & $\begin{array}{l}\text { La cercanía de sus } \\
\text { miradas significa } \\
\text { que tienen una } \\
\text { relación estrecha } \\
\text { donde no existen } \\
\text { limitaciones, ni las } \\
\text { leyes harán que } \\
\text { dejen de defenderse } \\
\text { el uno al otro; el } \\
\text { corazón de alambres } \\
\text { significa que es una } \\
\text { relación con } \\
\text { sufrimientos }\end{array}$ & $\begin{array}{l}\text { Nadine viste de } \\
\text { monja porque el } \\
\text { pueblo la ve buena y } \\
\text { es la preferida, pero } \\
\text { la corona de espinas } \\
\text { significa que tiene } \\
\text { una doble cara, que } \\
\text { hay alguien que no } \\
\text { le cree. El avión } \\
\text { representa los viajes } \\
\text { que ha venido } \\
\text { haciendo por } \\
\text { motivos } \\
\text { desconocidos }\end{array}$ & $\begin{array}{l}\text { PPK sale rebotando } \\
\text { de felicidad de una } \\
\text { caja de sorpresas } \\
\text { porque después de las } \\
\text { elecciones de la } \\
\text { segunda vuelta } \\
\text { recibió la noticia de } \\
\text { que llevaba la } \\
\text { delantera en la } \\
\text { intención de sufragio } \\
\text { de los votantes }\end{array}$ \\
\hline $\begin{array}{l}\text { Aspectos } \\
\text { subjetivos }\end{array}$ & $\begin{array}{l}\text { Se estaba } \\
\text { quedando atrás } \\
\text { en comparación } \\
\text { con sus } \\
\text { oponentes } \\
\text { Realiza ajustes } \\
\text { como evitar } \\
\text { ciertos aliados, } \\
\text { asistir a mítines, } \\
\text { dar discursos. Si } \\
\text { se quiere } \\
\text { soluciones, hay } \\
\text { que amoldarse a } \\
\text { lo que se tiene }\end{array}$ & $\begin{array}{l}\text { Siempre se cubren } \\
\text { las espaldas el uno } \\
\text { al otro a pesar de } \\
\text { que todos sepamos } \\
\text { de que son unos } \\
\text { políticos corruptos }\end{array}$ & $\begin{array}{l}\text { Se aprovecha de la } \\
\text { presidencia de su } \\
\text { esposo para realizar } \\
\text { viajes más que } \\
\text { cualquier otra } \\
\text { primera dama; Se } \\
\text { "sacrifica" } \\
\text { escogiendo bien sus } \\
\text { viajes } \\
\text { También es } \\
\text { gobernadora }\end{array}$ & $\begin{array}{l}\text { La mayoría de } \\
\text { personas esperaba } \\
\text { que Keiko Fujimori } \\
\text { tenga más apoyo que } \\
\text { PPK, incluso ella } \\
\text { misma estaba muy } \\
\text { confiada de ello, pero } \\
\text { el giro que dio PPK } \\
\text { fue algo inesperado }\end{array}$ \\
\hline $\begin{array}{l}\text { Grado de } \\
\text { polisemia }\end{array}$ & $\begin{array}{l}\text { Lourdes quiere } \\
\text { verse más } \\
\text { delgada } \\
\text { UN hace ajustes } \\
\text { en su campaña }\end{array}$ & $\begin{array}{l}\text { Fujimori y } \\
\text { Montesinos se } \\
\text { cubren el uno al otro } \\
\text { a pesar de las } \\
\text { dificultades }\end{array}$ & $\begin{array}{l}\text { Nadine es pura y } \\
\text { buena, pero hay } \\
\text { gente que no le cree } \\
\text { nada } \\
\text { Nadine hace de } \\
\text { presidente haciendo } \\
\text { lo que quiere }\end{array}$ & $\begin{array}{l}\text { PPK está muy feliz } \\
\text { por las noticias que } \\
\text { recibió } \\
\text { Las noticias fueron } \\
\text { una sorpresa } \\
\text { inesperada }\end{array}$ \\
\hline
\end{tabular}




\section{ANEXO 2: CUADRO DE ENTREVISTA VICTOR CH. VARGAS}

\begin{tabular}{|c|c|}
\hline Entrevistado & Víctor Ch. Vargas \\
\hline Cargo & Jefe de fotografía 1085-2015 (actualidad) \\
\hline Funciones & $\begin{array}{l}\text { El coordinador informa sobre las comisiones que hay que hacer y yo como } \\
\text { jefe de fotografía que conozco a los fotógrafos y sus estilos, digo quien va. }\end{array}$ \\
\hline $\begin{array}{ll}\text { Características de } \\
\text { las portadas de } \\
\text { Caretas }\end{array}$ & $\begin{array}{l}\text { Deben ser o muy reales o muy montadas. Se sabe cuándo es fotomontaje. } \\
\text { Es un chacondeo. Es una caricatura gráfica políticamente sarcástica. Se } \\
\text { juega con lo que ha pasado en la semana y se ven temas específicos. }\end{array}$ \\
\hline \multirow{4}{*}{ Proceso } & El fotógrafo hace 1 o 2 comisiones al día. Deja unas 10 fotos. \\
\hline & $\begin{array}{l}\text { El redactor pide al fotógrafo que le mande } 4 \text { fotos para poder } \\
\text { armar los espacios con el diagramador. }\end{array}$ \\
\hline & $\begin{array}{l}\text { El director revisa las fotos y ve cual va. Si no le gusta ninguna, } \\
\text { regresa a ver otras. El tiene la palabra final. }\end{array}$ \\
\hline & Pasa a diagramación final. \\
\hline \multirow{2}{*}{$\begin{array}{l}\text { Límites para la } \\
\text { manipulación }\end{array}$} & $\begin{array}{l}\text { Se puede hacer fotomontaje en las caratulas, porque es como una } \\
\text { ilustración en la que se quiere decir que pasó, pero en una foto no } \\
\text { porque eso es algo real. }\end{array}$ \\
\hline & $\begin{array}{l}\text { En el fotomontaje si se puedes borrar, limpiar, retocar. Se limpia } \\
\text { cuando las cámaras dejan puntos negros. Se puede arreglar } \\
\text { contraste o color, pero en la imagen no debe tocarse nada. }\end{array}$ \\
\hline $\begin{array}{l}\text { Objetivo de las } \\
\text { portadas }\end{array}$ & Tener una respuesta acerca de lo político. \\
\hline $\begin{array}{l}\text { ¿Se considera } \\
\text { manipulación? }\end{array}$ & $\begin{array}{l}\text { Esto no es manipulación. Una foto hecha no es manipulación. } \\
\text { Manipulación es cuando haces creer que esa foto fue en tal fecha con tal } \\
\text { persona o cuando pones a una persona que no ha estado. }\end{array}$ \\
\hline $\begin{array}{l}\text { Opinión sobre la } \\
\text { manipulación }\end{array}$ & $\begin{array}{l}\text { Manipulación en prensa no debe existir. A veces se ha visto en los } \\
\text { periódicos la manipulación y uno se da cuenta, pero eso no se debe hacer. } \\
\text { Si se manipula, es un engaño. }\end{array}$ \\
\hline
\end{tabular}


Casos

de Cuando toman una foto en la cancha al arquero y la pelota está ahí en la manipulación otros medios

en foto, pero eso es mentira, la pelota la han puesto porque no la agarraron en el encuadre. 


\section{ANEXO 3: CUADRO COMPARATIVO DE ENTREVISTAS JAIME RÁZURI Y ROBERTO GUERRERO}

\begin{tabular}{|c|c|c|}
\hline Entre & Ime Rázuri & Roberto Guerrero \\
\hline $\begin{array}{l}\text { Resumen de } \\
\text { trayectoria }\end{array}$ & $\begin{array}{l}\text { Trabajó en La República y Caretas. } \\
\text { Expuso en múltiples colectivos en el país } \\
\text { y en el extranjero. Realizó } \\
\text { fotodocumentalismo en temas de } \\
\text { identidad cultural (mestizaje y } \\
\text { "cholificación"). Hizo un proyecto extenso } \\
\text { de personas con VIH. Es el actual } \\
\text { responsable del área fotográfica de la } \\
\text { agencia de prensa France Presse de Lima } \\
\text { y profesor de la Universidad de Lima. }\end{array}$ & $\begin{array}{l}\text { Tiene } 35 \text { años en la carrera. Trabajó en } \\
\text { los diarios chilenos La Nación, Las } \\
\text { Ultimas Noticias y La Tercera, y el diario } \\
\text { peruano La República. Ha sido } \\
\text { coordinador académico en IPAD. Realiza } \\
\text { proyectos de prensa para el MMM. } \\
\text { Acaba de lanzar un libro fotográfico } \\
\text { llamado Andahuaylazo. }\end{array}$ \\
\hline $\begin{array}{l}\text { Opinión sobre } \\
\text { la } \\
\text { manipulación } \\
\text { digital en la } \\
\text { fotografía } \\
\text { periodística }\end{array}$ & $\begin{array}{l}\text { Si por la manipulación digital te refieres a } \\
\text { la alteración de una imagen y que eso no } \\
\text { corresponda a una situación informativa, } \\
\text { entonces no estoy de acuerdo, pero si te } \\
\text { refieres a hacer correcciones básicas y } \\
\text { elementales, obvio que si es más que } \\
\text { necesario. }\end{array}$ & $\begin{array}{l}\text { El fotoperiodista debe evitar la } \\
\text { manipulación. Tiene una obligación } \\
\text { social y es crear conciencia en la } \\
\text { sociedad. Es el nexo entre los hechos y } \\
\text { los lectores. Ese nexo debe ser lo más } \\
\text { objetivo posible. }\end{array}$ \\
\hline $\begin{array}{l}\text { Casos de } \\
\text { manipulación } \\
\text { en el Perú }\end{array}$ & $\begin{array}{l}\text { He visto menos de lo que realmente } \\
\text { sucede. He visto colocar una pelota en } \\
\text { donde no estaba. He visto manipulaciones } \\
\text { burdas, por ejemplo, en la web de El } \\
\text { Comercio. La última que circuló en la red } \\
\text { es la foto de Castañeda chequeando unas } \\
\text { obras de un túnel, pero en realidad nunca } \\
\text { estuvo ahí, sino que lo pastearon en la } \\
\text { imagen. }\end{array}$ & $\begin{array}{l}\text { Si una fotografía cuando se manipula, } \\
\text { como el caso de Caretas que juega con } \\
\text { personajes, va con un crédito que dice } \\
\text { que hicieron la manipulación, si es } \\
\text { permitido, porque tiene esa línea de } \\
\text { burlarse a través de la imagen y porque } \\
\text { el medio dice que es un truco, pero } \\
\text { cuando yo quiero basar una imagen como } \\
\text { cierta habiéndola manipulado, creo que } \\
\text { eso no es permitido. }\end{array}$ \\
\hline
\end{tabular}




\begin{tabular}{|c|c|c|}
\hline $\begin{array}{l}\text { Que hacer en } \\
\text { caso de que un } \\
\text { medio de } \\
\text { prensa hace } \\
\text { una } \\
\text { manipulación }\end{array}$ & $\begin{array}{l}\text { Hacerlo público. Es la única manera que } \\
\text { tiene la sociedad de corregirse a si misma. } \\
\text { Corregir las instituciones a las que } \\
\text { supuestamente se les está otorgando un } \\
\text { nivel de fiabilidad y de credibilidad. }\end{array}$ & $\begin{array}{l}\text { Desgraciadamente, a sociedad en general } \\
\text { no es crítica con los medios de } \\
\text { comunicación. Somos muy suaves al } \\
\text { momento de ser lectores. No podemos } \\
\text { dejar que nos manipulen, porque al } \\
\text { manipular una foto nos están } \\
\text { manipulando como lectores con } \\
\text { fotografías extremadamente trabajadas. }\end{array}$ \\
\hline $\begin{array}{l}\text { Pros y contras } \\
\text { de la } \\
\text { manipulación }\end{array}$ & $\begin{array}{l}\text { Pros: } \\
\text { Contras: el hecho de que se convierta en } \\
\text { una práctica común, en que todo el mundo } \\
\text { lo hace. }\end{array}$ & $\begin{array}{l}\text { Pros: } \\
\text { Contras: Pierde la credibilidad del lecto } \\
\text { No se está contando la realidad, está } \\
\text { tergiversando algo. Juega con la ética. }\end{array}$ \\
\hline $\begin{array}{l}\text { Que no se } \\
\text { debería hacer }\end{array}$ & $\begin{array}{l}\text { Colocar elementos donde no los hubo o } \\
\text { que un rostro esté demacrado y que } \\
\text { finalmente se muestre como algo que no } \\
\text { estuvo demacrado. Eso si es tergiversar. }\end{array}$ & $\begin{array}{l}\text { Yo me considero un fotógrafo que } \\
\text { mantiene la línea pura. Lo más que se } \\
\text { puede hacer es limpiarla. De repente salió } \\
\text { algo sucio o darle el contraste mínimo } \\
\text { que necesita, pero no puede alterar } \\
\text { colores, composición ni encuadres. }\end{array}$ \\
\hline $\begin{array}{ll}\text { Retoques } & \text { que } \\
\text { se hacen de } & \text { acuerdo a un } \\
\text { medio } & \text { de } \\
\text { prensa } & \\
\text { específico } & \end{array}$ & $\begin{array}{l}\text { Corresponde a los cánones, a las } \\
\text { necesidades editoriales de la revista en } \\
\text { relación a su público, sino no se va a } \\
\text { comprar tanto la revista, el lector común y } \\
\text { corriente no se va a identificar. Ellos } \\
\text { necesitan que se venda. }\end{array}$ & $\begin{array}{l}\text { Estamos pensando en vender periódicos. } \\
\text { Con tal de entrar a leerlo te ponen } \\
\text { cualquier cosa. Publicidad, más ingreso. } \\
\text { Eso no califica para nada en } \\
\text { fotoperiodismo. }\end{array}$ \\
\hline $\begin{array}{l}\text { Consecuencias } \\
\text { para el medio } \\
\text { de prensa que } \\
\text { utiliza } \\
\text { manipulación }\end{array}$ & $\begin{array}{l}\text { Si la cosa no se vuelve un escándalo, si no } \\
\text { hay una forma de hacer que sea público, } \\
\text { no pasa nada. }\end{array}$ & $\begin{array}{l}\text { Los medios deben tener un respeto por el } \\
\text { trabajo del fotoperiodista, porque está } \\
\text { mostrando un producto y tiene que ser } \\
\text { real. Tiene que ser creible. Si se pierde } \\
\text { ese nexo, esa comunicación con el lector, } \\
\text { estás perdiendo público y credibilidad. Se } \\
\text { crea un mal criterio de opinión en los } \\
\text { lectores. }\end{array}$ \\
\hline
\end{tabular}




\begin{tabular}{|c|c|c|}
\hline $\begin{array}{l}\text { Existencia de } \\
\text { un código de } \\
\text { ética del } \\
\text { fotoperiodista } \\
\text { en el Perú }\end{array}$ & $\begin{array}{l}\text { No hay un ente rector que diga cuales son } \\
\text { los parámetros para todos los medios. Ahí } \\
\text { entra el tema de la libertad de expresión a } \\
\text { veces como un criterio, pero al interior del } \\
\text { medio si tienen códigos implícitos o } \\
\text { hablados, o en algunos casos hay un } \\
\text { manual. }\end{array}$ & $\begin{array}{l}\text { Hay manuales de estilo que tienen los } \\
\text { periódicos donde dicen bajo que normas } \\
\text { se pueden regir los profesionales, pero } \\
\text { siempre se habla del respeto a la imagen. } \\
\text { Habría que ver que dicen esos manuales. }\end{array}$ \\
\hline $\begin{array}{l}\text { Necesidad de } \\
\text { un código de } \\
\text { ética del } \\
\text { fotoperiodista }\end{array}$ & $\begin{array}{l}\text { Yo creo que debería haber. Debería haber } \\
\text { una definición de cosas y se haga un } \\
\text { respeto de esa definición, pero también se } \\
\text { tomen las cosas flexiblemente. No afectar } \\
\text { la sensibilidad del público. Es una } \\
\text { cuestión de educación, de formación, de } \\
\text { opinión pública, de conciencia de porque } \\
\text { suceden las cosas. }\end{array}$ & $\begin{array}{l}\text { La ética no es ética chiquitita o ética } \\
\text { mediana o ética grande. Eso no puede } \\
\text { ser. La ética es ética. El fotógrafo de } \\
\text { prensa debe replantearse, porque estamos } \\
\text { presenciando su desaparición. }\end{array}$ \\
\hline
\end{tabular}




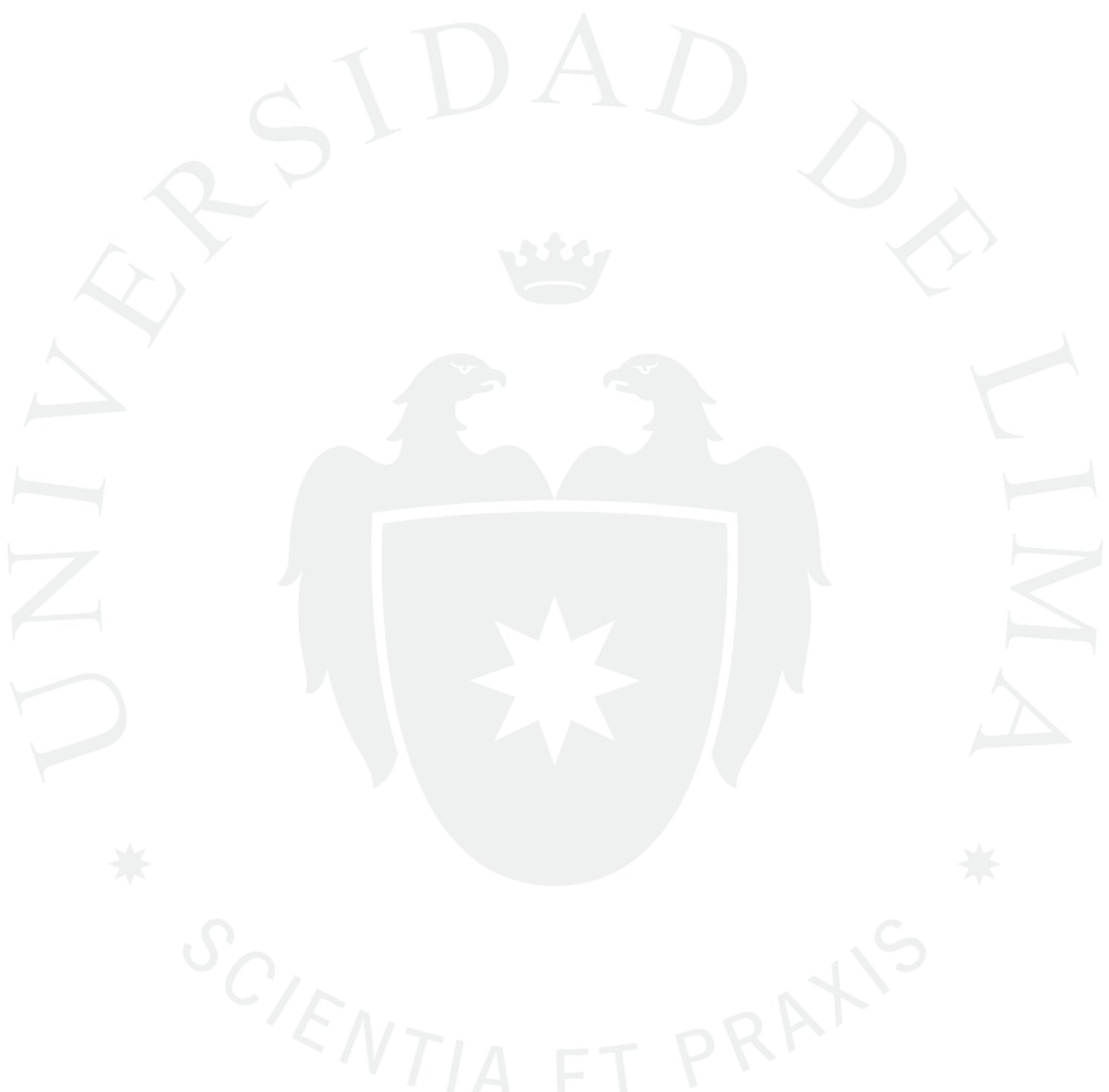

\section{ÍNDICE DE FIGURAS}

Figura 1. Lourdes

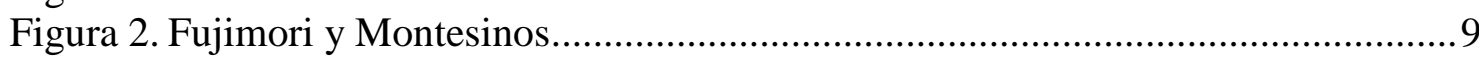

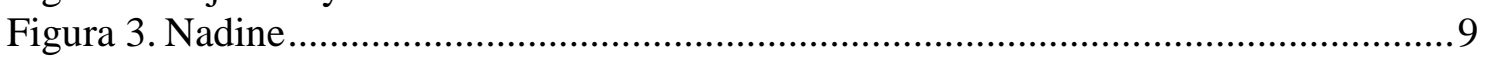

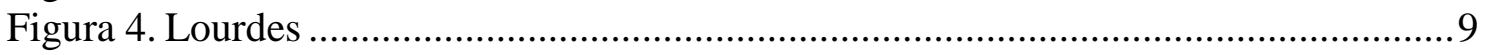




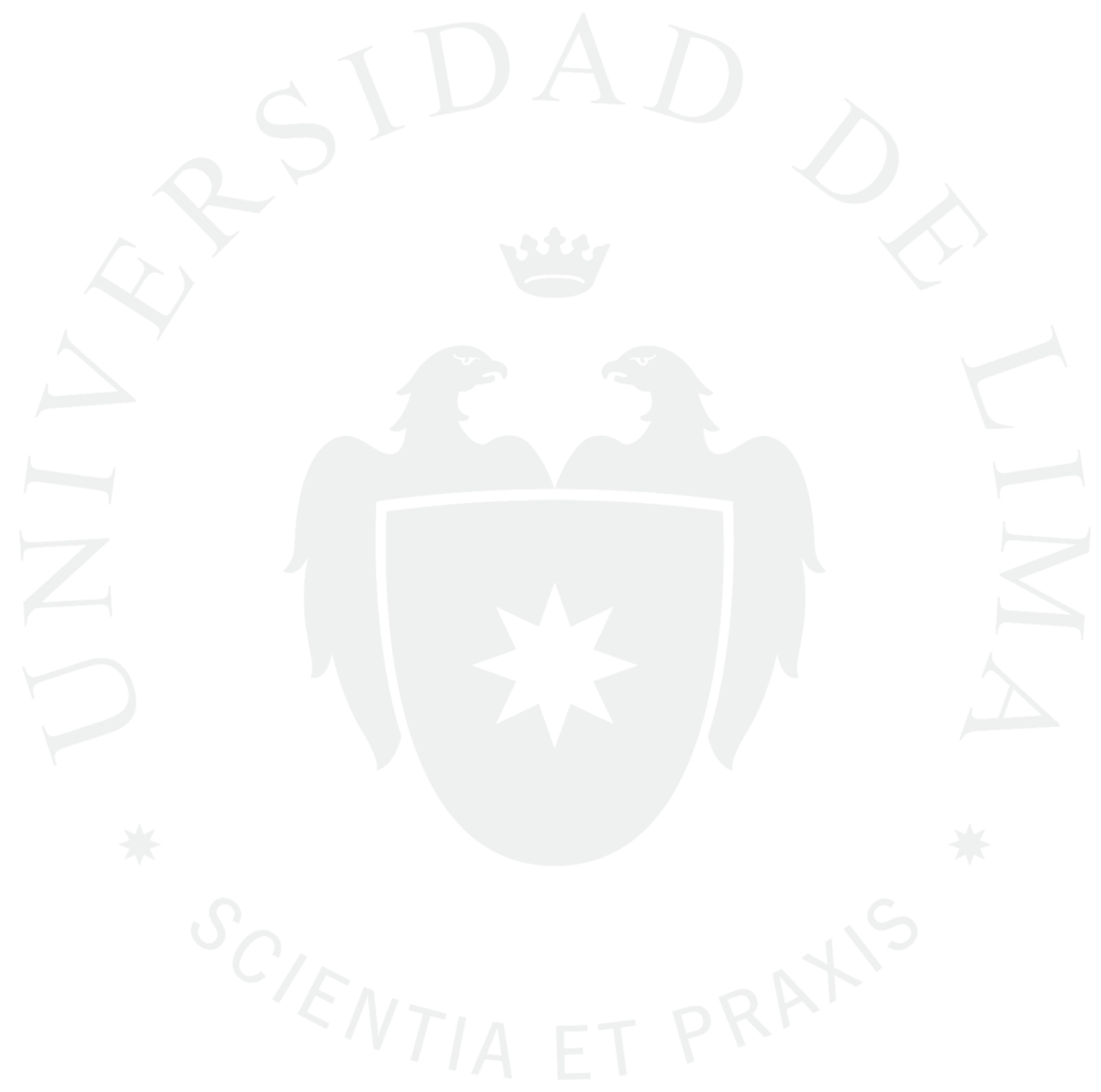

